ISSN electrónico: 2172-9077

DOI: https://doi.org/10.14201/fjc201919117146

\title{
NARRATIVAS DE IDA Y VUELTA: APROPIACIONES, INFLUENCIAS Y CONTAMINACIONES MUTUAS ENTRE PINTURA, FOTOGRAFÍA Y CINE
}

\section{Round Trip Narratives: Appropriations, Influences and Mutual Contamination between Painting, Photography and Cinema}

\author{
Dr. José GÓMEZ-ISLA \\ Profesor Titular de la Universidad de Salamanca, España \\ E-mail: pepeisla@usal.es \\ (iD) URL del código ORCID: 0000-0003-1915-933X
}

Fecha de recepción del artículo: 15/09/2019

Fecha de aceptación definitiva: 23/10/2019

\begin{abstract}
RESUMEN
El presente ensayo aborda el fenómeno de las fronteras móviles y las contaminaciones mutuas que se producen entre distintos medios visuales. La aparición de las nuevas tecnologías visuales, entre el s. XIX y el XX, obligaría a los medios anteriores (como la pintura o el dibujo) a repensarse tal y como estaban concebidos. A su vez, esas tecnologías emergentes se han servido a menudo de sus predecesores para nutrirse y tomar prestadas algunas de sus formas expresivas. Muchos creadores, ya procedan desde uno u otro medio, han reflexionado con sus obras sobre la interacción existente entre los diferentes códigos lingüísticos que permean entre todas esas disciplinas, lo que les permite seguir reformulándose e innovar en sus narrativas específicas.

$\mathrm{El}$ artículo analiza algunos de esos hitos que, a lo largo de los últimos dos siglos, han impulsado las propuestas intermediales procedentes de la pintura, la fotografía o el cine, llegando a generar ciertas poéticas híbridas en los espacios intersticiales existentes entre todas estas disciplinas.
\end{abstract}

Palabras clave: Medios visuales, Especificidad discursiva, Contaminación lingüística, Intermedialidad, Hibridación narrativa.

\begin{abstract}
The following essay analyzes the phenomenon of mobile frontiers and the accompanying contamination that is produced across different visual media. The development of new visual technologies, between the 19th and 20th centuries, forced prior media (such as painting and drawing) to reinvent themselves fully. Concurrently, these emerging technologies have often taken inspiration from their predecessors. Many artists, having reflected on their creations and the interaction between different linguistic codes that permeate all mentioned disciplines, are able to continue to grow and innovate throughout their specific narratives.

This article analyzes some of these historic milestones which, during these last two centuries, have enhanced cross-media proposals originating from painting, photography,
\end{abstract}


or film industry, and have generated some hybridized poetics filling the gap existing between disciplines.

Key words: Medios visuales, Especificidad discursiva, Contaminación lingüística, Intermedialidad, Hibridación narrativa.

«...ya no es solamente un medio aislado el que domina, sino que los medios interactúan y se condicionan mutuamente»

Peter Weibel. La Condición Postmedia, 2006.

\section{Introducción}

Los códigos expresivos tanto de las artes plásticas como de los medios visuales no son fijos e inamovibles. Presentan, como poco, fronteras disciplinares que se desplazan entre territorios conceptuales y formales, lo que les permite redefinirse constantemente en función de la época y la influencia ejercida por otros medios precedentes. Igualmente, los cimientos sólidamente asentados de ciertas disciplinas históricas (como la pintura o el dibujo) también se tambalean cada vez que entra en escena un nuevo medio visual -que generalmente viene precedido por el descubrimiento de una tecnología innovadora que revoluciona y pone en cuestión los viejos modos de producción-. Esta circunstancia provoca tales sacudidas sísmicas, que terminan por socavar y desmoronar los cimientos de esos viejos medios, tal y como habían sido concebidos históricamente. Pero dichas convulsiones también suponen una oportunidad inmejorable para ayudar a esas disciplinas a repensarse, evolucionar y reformularse en tanto que prácticas y medios visuales de expresión.

Uno de los casos más claros de revolución tecnológica fue el que protagonizó la fotografía en su momento fundacional. Las nuevas imágenes técnicas, que en sus comienzos utilizaron algunas de las estrategias narrativas tradicionales de la pintura (como la puesta en escena propia de género histórico, mitológico o religioso), copiando incluso sus códigos estilísticos y acabados formales, lograrían adquirir con el tiempo una especificidad discursiva que se iría alejando paulatinamente de los modos pictóricos de los que originalmente se nutrió:

"La experiencia demuestra que cuando un nuevo medio se incorpora a la arena mediática, genera numerosas búsquedas discursivas y lingüísticas de sus señas de identidad. El tortuoso proceso de búsqueda de esas señas distintivas no está exento de tensiones, contradicciones, flagrantes usurpaciones lingüísticas, intereses particulares de índole económica o política, sesgos ideológicos y caminos divergentes» (Gómez-Isla, 2008, p. 9).

De igual forma, y en sentido inverso, la influencia de la propia fotografía sobre el resto de las artes resultaría tan decisiva tras su periodo fundacional que conseguiría que buena parte de las formas productivas clásicas de la pintura o el dibujo resultaran prácticamente irreconocibles con el transcurso de las décadas.

A lo largo de este ensayo analizaremos diversos hitos históricos donde las prácticas fotográficas, por ejemplo, se afanaron por convertirse en una disciplina artística en toda regla $-\mathrm{y}$ a toda costa-, mirando para ello siempre de reojo a la pintura. Con este proceder, los fotógrafos-artistas no serían conscientes de estar obviando la propia 
naturaleza técnica de sus imágenes, intentando cuando menos disimular los procesos mecánicos y ópticos a los que les obligaban esos dispositivos de registro y edición.

Asimismo, veremos cómo el propio arte de la pintura, con varios siglos de tradición continuista en sus modos de producción -al menos desde el Renacimiento-, también se vería brutalmente sacudido por la aparición del medio fotográfico, hasta el punto de ver cómo las nuevas prácticas audiovisuales conseguían socavar y modificar para siempre los estatutos del arte mismo.

Analizaremos también determinados hitos artísticos que, comenzando en la segunda mitad del s. XIX, y atravesando buena parte de las vanguardias artísticas del $\mathrm{XX}$-sobre todo, durante el periodo de entreguerras-, fueron enormemente afectados por esos nuevos modos de producción que las técnicas audiovisuales habían inaugurado.

Con la llegada del cinematógrafo a finales del XIX, que instauraría una particular narrativa visual, basada esencialmente en el montaje -algo habitual tras la primera década del XX-, todo habría de reformularse nuevamente para el arte. Los códigos que empezaron a compartir e intercambiar entre sí estas tres disciplinas visuales (pintura, fotografía y cine) generarían a su vez un nuevo conjunto de poéticas que les ayudarían a evolucionar y transformarse mediante préstamos estéticos y lingüísticos entre sus respectivas propuestas discursivas donde la especificidad de cada medio dejó de ser la norma. Esos constantes préstamos intermediales y la institucionalización paulatina de cada uno de esos medios que entraba en escena (primero la fotografía y después el cine) mediante la consolidación de un aparato crítico propio, fueron generando el caldo de cultivo apropiado -mediante vasos comunicantes- para construir nuevos relatos que lograrían redefinir a la postre la lógica discursiva de cada uno de estos medios. Por último, la llegada de las nuevas tecnologías digitales, que atravesarán de cabo a rabo los modos tradicionales de producción visual, ha generado en las últimas décadas nuevos seísmos disciplinares e institucionales donde la redefinición de los medios anteriores pasa nuevamente por la hibridación entre ellos y una difuminación aún mayor entre fronteras disciplinares.

En este ensayo analizamos algunos de esos momentos clave, donde los procesos de Intermedialidad y redefinición institucional hacen más claros y visibles los trasvases, préstamos e influencias entre todas estas disciplinas.

\section{Objetivos e Hipótesis}

El objetivo de este análisis es poner de manifiesto la movilidad de los medios visuales y sus prácticas, deslizándose constantemente sobre placas tectónicas inestables, no sólo por las innovaciones técnicas que van surgiendo en cada medio, sino por los constantes cambios e intercambios en sus modos de producción que comprenden y abarcan nuevos territorios intermediales al "contaminarse» con otras disciplinas con las que, aparentemente, no compartían espacio hasta ese momento.

La principal hipótesis que manejamos es que las instituciones que definen a cada uno de esos medios visuales han ido reformulándolos paulatinamente, casi siempre, a medida que otro nuevo medio aparecía en escena, con la consiguiente innovación técnica y lingüística que su génesis conllevaba. Esto produce lógicamente ganancias y pérdidas en cada una de las disciplinas. Cualquier innovación tecnológica de un medio conlleva a su vez -inevitablemente-, reformulaciones a nivel conceptual y 
lingüístico de ese mismo medio y de sus precedentes. Si bien no queremos caer aquí en un determinismo tecnológico simplista, no podemos obviar el poder de la tecnología para reformular y recombinar los modos de producción visual y, en consecuencia, los nuevos lenguajes que de ellos se derivan.

«Vincularé siempre el desarrollo de un dispositivo técnico con el de un problema específico de emergencia de lenguajes: no tanto porque considere que la tecnología es destino cuanto porque, más bien, considero que ella, la tecnología, es lenguaje (...) Una historia de las formas sería inabordable sin la consideración de los dispositivos tecnológicos que articulan la relación de la producción simbólica con el mundo, con lo real» (Brea, 2002, p. 26).

Sólo mediante la experimentación técnica producida desde los nuevos medios, los creadores visuales serán capaces de apropiarse de esos nuevos modos de producción y sus prácticas derivadas para reflexionar críticamente sobre las fronteras, especificidades o inespecificidades discursivas que redefinen cada uno de esos medios mediante su peculiar movilidad lingüística.

De igual modo, este artículo analiza los distintos modos de representación simbólica del flujo temporal a través de los distintos soportes visuales y cómo buena parte de las disciplinas, contaminadas por las tecnologías surgidas en esos nuevos medios, ha ido modificando sus estrategias discursivas en torno a la plasmación de la cuarta dimensión.

\section{Análisis y Discusión}

Lo que iba camino de convertirse en uno de los primeros golpes «mortales» -y aparentemente definitivos- asestados a la pintura, tomaría forma con la reconversión de un viejo dispositivo óptico: la cámara oscura, transformada durante el s. XIX, en cámara fotográfica ${ }^{1}$. Esa cámara primigenia (la oscura) ya había sido ampliamente utilizada en Europa desde el Renacimiento como herramienta auxiliar del dibujo. Es lógico, por tanto, que teóricos como Victor Burgin hayan sostenido que los sistemas de representación de pintura y fotografía son en esencia idénticos, ya que ambos dependían directa o indirectamente de esa cámara originaria (Burgin, 1980). Pero, al asociarse -ya de forma indisoluble- con el fenómeno de la fotosensibilidad, la cámara oscura pasaría de ser una simple herramienta para convertirse en «artefacto tecnológico». La nueva asociación entre la óptica y la química dentro de un mismo dispositivo conllevaría también el desarrollo de una mayor precisión técnica. La exactitud en el cálculo y la medición del tiempo, así como el control de la cantidad de luz que su manipulación requería en cada caso, otorgaría a la nueva cámara y sus producciones un carácter cada vez más mecánico y maquínico. La irrupción fulgurante de estas primeras «imágenes técnicas» (primero fotográficas y después fílmicas), capaces de

1. La pintura, como ya casi nadie ignora, lleva muriéndose o, en su defecto, siendo asesinada sistemáticamente, como poco, cada veinte años, quinquenio arriba o quinquenio abajo. Sin embargo, no hay que asustarse. Como el Ave Fénix, esta disciplina siempre acaba renaciendo de sus cenizas. Después de tanto asesinato fallido, siempre surgen nuevos profetas milenaristas que anuncian una nueva "muerte de la pintura" con sonido de trompetas. La última de estas proclamas lleva produciéndose desde hace un par de décadas en Internet. 
"fijar instantes de realidad" capturados por el objetivo de la cámara (y sin "aparente» intervención humana), se convertirían desde su inicio en una seria amenaza para la pervivencia y utilidad de cualquier otra imagen generada artesanalmente que pretendiese representar simbólicamente el universo que habitamos. Esa amenaza se cernía sobre la totalidad del espectro de imágenes producidas manualmente (mediante la interpretación personal del ojo y la maestría de su productor al ejecutarlas), es decir, sobre cualquier imagen generada por el ser humano anterior a la fotografía misma, incluyendo, por supuesto, el arte de la pintura y el dibujo.

Como afirmaron algunos de los primeros críticos de la época, cuando «la naturaleza se copia a sí misma [sic]» a través de la cámara fotográfica (Baudelarie, 1859)² y, cuando décadas después, la nueva forma de representación adquiere movimiento en la pantalla de cine, a la pintura, al dibujo -y, en general, al conjunto de las artes tradicionales- no les quedaba otra salida más que la de sufrir una de sus primeras crisis de identidad. Era cuestión de renovarse o morir. Esta crisis desembocaría -como no podía ser de otro modo- en un proceso urgente de reflexión, de profunda renovación de sus fundamentos ontológicos, replanteándose incluso, más que una mera evolución natural en su estilo, una completa redefinición de su razón de ser a nivel social, ideológico y estético. En el instante en que, para generar imágenes «realistas y correctas»-según el dictado de la época-, ya no fueron necesarios ni el arduo aprendizaje de una determinada disciplina artística ni el virtuosismo técnico de un oficio concreto, la pintura se vería obligada a reformularse profundamente como lenguaje. Así, conceptos como "verismo» $\mathrm{O}$ "fidelidad óptica» pasarían definitivamente a ocupar un segundo plano en el modelo de representación del arte pictórico futuro. A partir de ese momento, el creador plástico tuvo que evitar caer en la absurda tentación de copiar literalmente las imágenes que cualquier cámara podía producir supuestamente con mayor exactitud e infinitamente más rápido. Por otro lado, sin la interpretación personal del creador, parecía que ya no era factible arte alguno. El relevo natural de la "restitución óptica», anhelado por los viejos pintores naturalistas, y reformulado ahora por la «objetividad» visual de la época, sería recogido por la tecnología fotográfica dejando algunas de las prácticas pictóricas tradicionales prácticamente sin función alguna (Daston y Galison, 2007). Si los primeros daguerrotipos habían sido comparados poéticamente con «espejos con

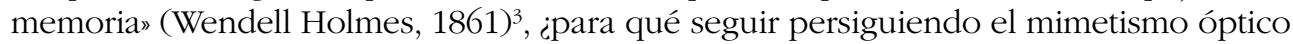
desde la pintura? Desde su origen, las prácticas fotográficas han paseado orgullosas la enseña de la exactitud mecánica y la fidelidad óptica respecto al motivo fotografiado o filmado. Pero esta tesis, como se verá más adelante, se volverá problemática cuando algunos fotógrafos del último tercio del XIX pretendan investir su trabajo de una

2. "En materia de pintura y de estatuaria, el Credo actual de las gentes de mundo, sobre todo en Francia (y no creo que nadie se atreva a afirmar lo contrario), es éste: 'Creo en la naturaleza y no creo más que en la naturaleza (hay buenas razones para ello). Creo que el arte es y no puede ser más que la reproducción exacta de la naturaleza (...). De este modo, la industria que nos diera un resultado idéntico a la naturaleza sería el arte absoluto'» Baudelaire, Charles (1859), "Le public moderne et la photographie», escrita a le Directeur de la Revue Française, París. Crítica al salón de 1859, en Le Revue Française, París.

3. El término "espejo con memoria" fue acuñado por el médico americano Oliver Wendell Holmes, también hombre de letras y fotógrafo amateur. Esta metáfora aparece recogida por primera vez en su artículo «Sun-Painting and Sun Sculpture», en Atlantic Monthly, vol. 8 (1861), pp. 13-29.

Cfr. Newhall, Beaumont. The History of Photography from 1839 to the Present Day. Museum of Modern Art, New York, 1964, pp. 30 y 31. 
determinada pátina artística. Estos fotógrafos-artistas utilizaron multitud de recursos artesanales, posproducidos en el laboratorio (mediante procesos pigmentarios, sobre todo), para conseguir acabados estilísticos más cercanos a la pintura o al dibujo que a la naturaleza mecánica de su propio medio. Renunciando a las cualidades técnicas de los dispositivos fotográficos -el enfoque nítido y el realismo-, sus trabajos derivaron en una corriente heterogénea que se distribuiría por media Europa y que, con el tiempo, se daría en llamar "pictorialismo fotográfico".

Sin embargo, una vez amortizado el movimiento pictorialista, ya en los albores del XX, cualquier creador fotográfico o cinematográfico mínimamente avezado sería capaz de utilizar sin complejos «artistizantes» sus respectivas tecnologías para construir un relato adecuado, acorde a los cánones institucionales y sociales de su época. Por tanto, estos autores acuñarían también nuevas formas expresivas para interpretar la realidad desde una óptica cada vez más personal -y conscientemente subjetiva-. Este modus operandi, centrado en las propiedades específicas de cada medio, sin mirar ya hacia otro lado, les permitiría a los nuevos autores aprovechar los recursos propios de las técnicas fotográfica y fílmica (ya sin ningún préstamo o impostura pictórica) para generar ciertos rasgos distintivos rápidamente asimilados e institucionalizados como nuevas formas de sintaxis visual.

Bien es cierto que, como apuntan Gaudreault y Marion, en el caso del cine esta sintaxis se iría forjando lentamente a lo largo de varias décadas. Según estos autores, el cine habría disfrutado de un "doble nacimiento». El primero de ellos se produciría en 1895, con la aparición del dispositivo técnico que permitía la captación de imágenes en movimiento, su reproducción y su exhibición ante el público. El segundo nacimiento, en cambio, se podría datar de su popularización como medio narrativo a finales de la primera década del s. XX (Gaudreault y Marion, 2007). Este segundo nacimiento conllevaría, como también apunta el historiador Fernando González, un proceso de institucionalización del cine a partir de la profesionalización de diversos agentes (asociaciones, crítica, estudiosos y público):

«Su segundo nacimiento estaría subrayado por la distinción: se trataría ya de un modo de disfrutar, por parte del público, de un dispositivo que despliega, sobre todo, narraciones, lo que traería consigo no solo la creación de una industria (Paech, 2010), sino también una incipiente crítica, unas primeras incursiones académicas, asociaciones profesionales y hasta, como veremos, lobbies de presión. Es decir, la formación de un complejo institucional»(González García, 2019, p. 21).

Por un proceso similar, la fotografía solo pasaría a concebirse como práctica discursiva tras un largo periodo que iría desde su aparición como "técnica» (1839) hasta cobrar carta de naturaleza institucional como «medio» visual. Pero, en este caso, más bien serían los usos derivados de la propia técnica los que permitirían clasificar las prácticas fotográficas en ámbitos profesionales y amateurs diferenciados, provocando con ello la aparición de diversos campos de especialización allí donde la fotografía era aplicaba. En su recorrido histórico, el medio fotográfico ha sido igualmente atravesado por multitud de intereses, ideologías, funciones sociales e innovaciones técnicas, por lo que no siempre ha adoptado una lógica evolutiva predecible. Por ejemplo, la amateurización del medio fotográfico con la popularización de las primeras cámaras Kodak que utilizaron película en rollo (desde 1888), gracias al empeño de su fundador George Eastman, generaría un ingente corpus de aficionados (sin grandes conocimientos técnicos). Esta circunstancia transformaría sustancialmente conceptos 
como el de álbum de familia o el de fotografía de viajes. Todos estos factores se irían incorporando paulatinamente en función de los contextos culturales dominantes, las innovaciones técnicas y los ámbitos donde las fotografías se producían y difundían. De la misma manera, sus significados tampoco han permanecido fijos en función de la época: siempre han estado sujetos a nuevas lecturas, a enormes tensiones ideológicas y sociales y a variaciones constantes de sentido dependiendo del contexto social y cultural en el que aparecen y se consumen.

Al igual que el cine, la técnica fotográfica se fue convirtiendo paulatinamente en "medio» al dotarse de un aparato crítico especializado y de un amplio abanico de profesionales, estudiosos, agentes, industrias y consumidores. Consecuentemente, la institucionalización del medio fotográfico se produciría tras varias décadas de desarrollo como técnica. Sin embargo, no podemos obviar que este medio carece de una historia unitaria y coherente, como afirma Geoffrey Batchen:

"La fotografía no puede entenderse como una identidad estática o una posición cultural singular. Es mejor considerarla [...] como un campo disperso y dinámico de tecnologías, prácticas e imágenes. La condescendiente ubicuidad de este campo fotográfico es tal que resulta indistinguible de las instituciones o discursos que deciden hacer uso de ella. La historia de la fotografía es, por tanto, la historia colectiva y variopinta de esas mismas instituciones y discursos» (Batchen, 2004, p. 13).

Puesto que desde su origen la fotografía ha venido afectando a diversos contextos sociales, históricos y ámbitos de aplicación, aquellas instituciones que, gracias a ella, fueron redefiniéndose y renovándose durante la segunda mitad del XIX serían las mismas que también terminarían a su vez por redefinir las prácticas, funciones y significados de la propia fotografía en tanto que medio visual heterogéneo. Como apunta John Tagg, si la identidad de la fotografía ha sido tan cambiante es consecuencia directa de su transformación constante en los ámbitos institucionales y de poder a los que sirve:

«La fotografía como tal carece de identidad. Su posición como tecnología varía con las relaciones de poder que la impregnan. Su naturaleza como práctica depende de las instituciones y de los agentes que la definen y la ponen en funcionamiento. Su función como modo de producción cultural está vinculada a unas condiciones de existencia definidas, y sus productos son significativos y legibles solamente dentro de los usos específicos que se le dan. Su historia no tiene unidad. Es un revoloteo por un campo de espacios institucionales. Lo que debemos estudiar es ese campo, no la fotografía como tal» (Tagg, 2005, p. 85).

Por su parte, (en la tercera pata de esta tríada visual) aquellos pintores realistas, que en su momento abjuraron de la imagen mecánica (ya fuese por la frialdad de su acabado, ya por su exactitud visual), se vieron abocados con el tiempo a reinventar su propio lenguaje para enterrar definitivamente los postulados reaccionarios de la pintura decimonónica. De esta forma, la pintura comenzó a liberarse definitivamente de las ataduras de fidelidad respecto al modelo representado que el empuje del progreso fotográfico y cinematográfico estaba dejando literalmente en la cuneta. Así ocurrió con la miríada de retratistas y miniaturistas que trabajaban por encargo y que fueron desapareciendo progresivamente en la segunda mitad del s. XIX o reconvirtiéndose ellos mismos en fotógrafos. Walter Benjamin daría fe de esta convulsión 
producida en el régimen de la visualidad entre finales del XIX y principios del XX a través de una de sus «tesis de filosofía de la historia». En ella el filósofo se haría eco del progreso imparable al que nos empujaba la tecnología y sus imágenes, los datos y repertorios que generaban y, por descontado, la impregnación social de sus nuevas lógicas y modos de producción:

«Y este deberá ser el aspecto del ángel de la historia. Ha vuelto el rostro hacia el pasado. Donde a nosotros se nos manifiesta una cadena de datos, él ve una catástrofe única que amontona incansablemente ruina sobre ruina, arrojándola a sus pies. (...) Ese huracán le empuja irrepetiblemente hacia el futuro, al cual da la espalda, mientras que los montones de ruinas crecen ante él hasta el cielo. Ese huracán es lo que nosotros llamamos progreso» (Benjamin, 1940, p. 183).

Pese a todo, la aparición de las imágenes técnicas supondría un cambio cualitativo que iría mucho más allá de la archicitada pérdida del «aura» de la que, según el propio Benjamin, habían venido gozando las imágenes artísticas tradicionales en tanto que "valor de culto». Ese "aura" (el "aquí y ahora» de toda obra de arte única e irrepetible) al que el filósofo alemán se refería en otro célebre ensayo, comenzaría a desmoronarse a principios del XX debido al imparable desarrollo de las técnicas fotomecánicas e industriales que permitían reproducir esas obras ad infinitum (Benjamin, 1936).

De igual modo, y gracias a las innovaciones técnicas del medio fotográfico (entre el último tercio del XIX e inicios del XX), la aparición de las nuevas instantáneas ${ }^{4}$ sorprendería al mundo entero fijando, en fracciones infinitesimales de tiempo y luz, unas formas de representación inéditas para la percepción visual de la época. Esas innovaciones consiguieron hacer visible lo que había resultado hasta entonces imperceptible por observación directa. Todo esto obligaría también a los nuevos creadores plásticos a lanzarse a una experimentación sin tregua de nuevas formas de concebir el mundo, aunque siempre dentro del espacio bidimensional del cuadro. Para conseguirlo, tuvieron que romper con el tradicional «cajón escénico albertiano» que había sido instaurado desde el Renacimiento como sistema hegemónico de representación visual, a raíz de la invención de la perspectiva (Alberti, 1511). Este sistema de representación había permanecido prácticamente inalterado durante más de cuatro siglos, hasta los albores del siglo XX. En consecuencia, gracias a las innovaciones técnicas y lingüísticas que introdujeron la fotografía y el cine, y a las cualidades propias de la cámara en tanto que dispositivo, el ojo fijo del Renacimiento pasaría inevitablemente a convertirse en el ojo móvil de la Modernidad. Como consecuencia de ello, la pintura tampoco se libraría de este nuevo modo de mirar.

No en vano, con las primeras vanguardias del XX, el artista moderno se lanzaría a la representación del movimiento frenético e incesante de la vida urbana. Ya no intentaría capturar lo eterno o lo esencial de la existencia, como había sido la costumbre generalizada de la pintura hasta entonces. Al contrario, estos nuevos artistas se esforzaron más que nunca por atrapar aquellos instantes fugaces de la vida cotidiana que, antes de haber sido plenamente percibidos por el ojo «lento» de la época,

4. La fotografía instantánea no aparece hasta 1873. El fotógrafo Eadweard Muybridge, tras arduos experimentos con emulsiones fotográficas más sensibles y mayor rapidez de obturación (en fracciones de un 1/500 segundos), consiguió fijar por primera vez, en una secuencia de 12 imágenes, el galope de un caballo. 
iniciaban su desaparición de la escena. Por esa razón, buena parte de los movimientos de la primera vanguardia estuvieron marcados por la fugacidad misma de la vida moderna y, consecuentemente, por el empuje de las nuevas técnicas visuales que permitían representarla. En ese momento de eclosión, las disciplinas plásticas tradicionales, no exentas de un cierto complejo ante este "empuje tecnológico", se sirvieron sin empacho de los artefactos mecánicos de registro visual que hasta entonces habían sido sus serios competidores. Pero también es cierto que, con determinada frecuencia, muchos de esos mismos artistas que se habían servido de la fotografía y el cine para componer sus obras, ocultaron pudorosamente las fuentes tecnológicas que les habían inspirado (Scharf, 1974).

Por su parte, ciertas corrientes de vanguardia se dedicaron de modo creciente a representar un universo vertiginoso de formas y sensaciones dinámicas. Más que formas y cuerpos definidos, o composiciones estáticas, estos pintores pretendían captar la incidencia cambiante de la luz y el paso fugaz del tiempo sobre esos mismos cuerpos. Con las mismas herramientas pictóricas de antaño, pero utilizadas de un modo nuevo, muchos de estos pintores emularon el movimiento mediante efectos como la borrosidad, que eran más propios de los ruidos generados por la cámara que de la percepción humana. La atmósfera de los lugares o el instante cambiante pasaron a ser los temas preferidos de los creadores del siglo XX, desde el cubismo y el futurismo italiano en adelante. Unas cuantas décadas antes, Claude Monet, pintor impresionista de ojo prodigioso, ya había intentado plasmar esa realidad huidiza y efímera. Motivos repetidos a distintas horas del día, o con distinta atmósfera, como La Catedral de Rouen (serie realizada entre 1892 y 1893) (figura 1) o la serie del Parlamento de Londres, inauguraron esos nuevos modos de representar el ritmo vital y sus instantes cambiantes. Monet introduciría así por vez primera el concepto de «serie» pictórica, relacionado, en cierto modo, con el de "secuencia temporal», un concepto que habría de reaparecer unos años más tarde con la invención del cine.

Figura 1. Claude Monet. Serie de «La catedral de Rouen», 1892-1893.
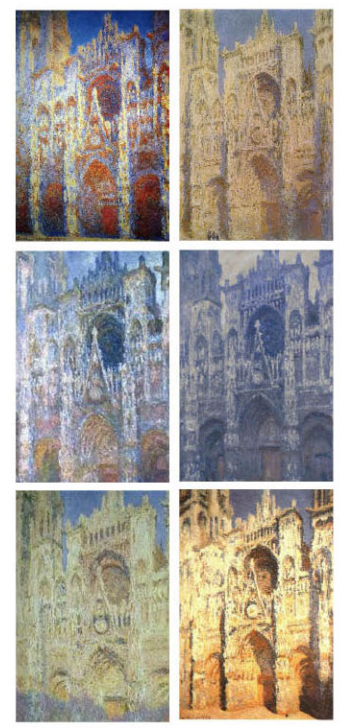
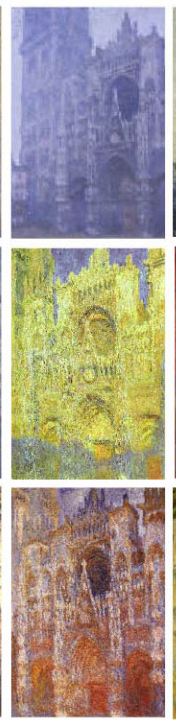
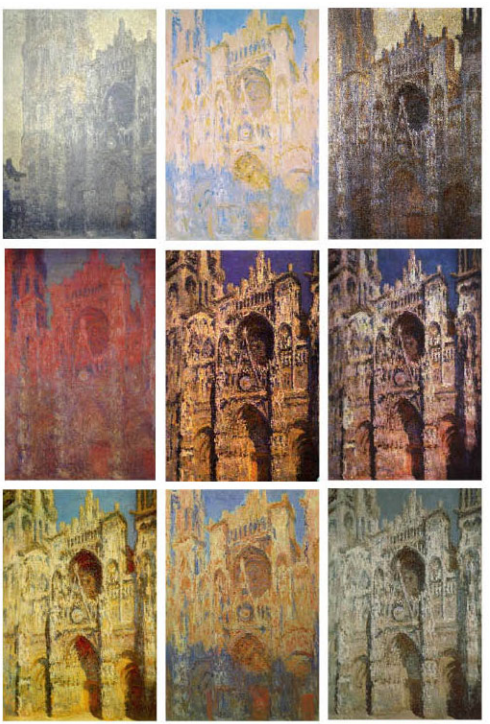
Figura 2. Paul Cézanne. «Study of Trees», c. 1904.

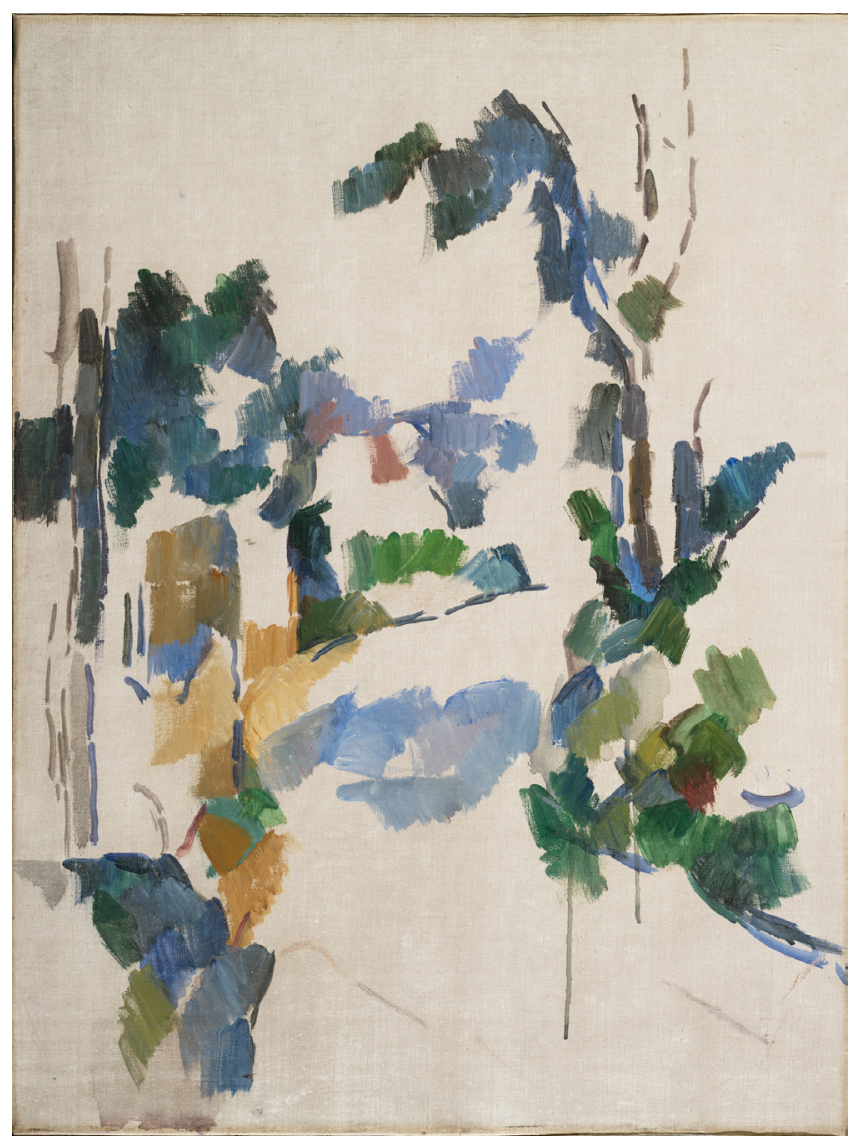

Pero, para que este cambio de paradigma visual se produjese, sería determinante otra renovación pictórica impulsada por Paul Cézanne. Su trabajo ayudó a levantar los nuevos pilares conceptuales sobre los que se asentaría décadas después la pintura contemporánea. Para Cézanne la auténtica razón de ser de la pintura ya no radicaba solamente en emular sensaciones lumínicas fugaces sobre los objetos, como habían hecho los impresionistas unas décadas antes. Más bien al contrario, y a diferencia de la precisión casi "fotográfica" de Monet y sus coetáneos, la óptica de Cézanne "radicaba más en el cerebro que en la vista» (Bernard, 1907). No es de extrañar por tanto que, para recrear los paisajes en sus lienzos, Cézanne se empeñara en conjugar varios puntos de vista simultáneos que, aunque levemente dispares, estaban ligados entre sí por un continuum temporal logrado mediante la unidad de ejecución de la obra. "La definitiva integración del tiempo en el espacio, iniciada por la instantánea fotográfica, alcanza en Cézanne su culminación y consigue la destrucción de las coordenadas clásicas de frontalidad, univocidad del punto de vista y fijación» (Herrera Navarro, 1982, p. 37). Mientras que el ojo de Monet permanecía fijo en el espacio y en el tiempo representados, congelando en cada obra lo efímero del momento percibido, a modo de «instantánea» fotográfica, Cézanne en cambio se iba a convertir en un ojo móvil, un ojo que se deslizaba sobre el referente para recrear una nueva sensación de movilidad, 
dinamismo y temporalidad (quizás más cercano al cine). Este modus operandi a la hora de ejecutar sus obras (a base de "parches" dispersos de color, como puede verse en un estudio inacabado de árboles, perteneciente a la colección de los Harvard Art Museums) ${ }^{5}$ (figura 2) generaría inevitablemente una suerte de multiplicidad de puntos de vista sobre el mismo plano de la representación, algo absolutamente inédito para la época.

Décadas más tarde, ciertos movimientos de vanguardia a inicios del s. XX acabarían adoptando como propias las enseñanzas de Cézanne, anteponiendo por vez primera la idea a la visión fidedigna de la realidad percibida. Los cubistas, por ejemplo, se centraron sobre todo en aspectos formales que la fotografía ya había intuido y experimentado mecánicamente, como la relatividad de la visión en movimiento y la multiplicidad de puntos de vista sobre un mismo plano de representación, la fragmentación del espacio y la destrucción de la perspectiva euclidiana, a cuyos dictados se había plegado la pintura durante siglos. El cubismo, al igual que Cézanne, también se rebeló contra el impresionismo precedente. Lo que verdaderamente reprochaban los cubistas, esencialmente Picasso y Braque, a los impresionistas era el exceso de "verosimilitud óptica" que adoptaban en sus obras, sin plantearse ninguna otra alternativa conceptual frente a la supremacía óptica de la imagen mecánica:

«Si algo reprochaban los cubistas al impresionismo era ser sólo retina y no cerebro. (...) No se trataba, pues, del registro puro y simple de los datos visivos, sino de su organización en una síntesis intelectual que, al efectuar una selección, destacase los datos esenciales» (Micheli, 1979, p. 197).

Lo que habían aprendido los cubistas de su involuntario «maestro» Cézanne, era el modo en que una secuencia temporal podía ser plasmada sobre el plano pictórico, es decir, la incorporación del tiempo dentro del espacio fijo y bidimensional del cuadro. A partir de entonces el creador contemporáneo tomará conciencia de esa percepción fragmentaria al plasmar de forma simultánea la realidad desde distintos puntos de vista.

Lo que los cubistas pusieron en práctica sobre sus telas, sería formulado teóricamente años más tarde por László Moholy-Nagy, creador plástico y teórico de la Bauhaus, en su ensayo La nueva visión (1929). En esta obra Moholy-Nagy defendía argumentos privativos de las prácticas cubistas, como lo que él denominó «el giro de los objetos", que permitía observar distintas partes de un mismo objeto al mismo tiempo de frente y de perfil; o lo que también define como el «desplazamiento, o dislocamiento de las partes». Según Moholy-Nagy, las nuevas formulaciones cubistas incluían también otros recursos formales como la «refracción de líneas de ruptura y ruptura de líneas continuas; Superposición de distintas vistas de los objetos; Introducción de líneas geométricas exactas, rectas y curvas; Cambios de líneas o planos positivos-negativos; Múltiples formas en una: Pluralismo. Un contorno se refiere a varias formas...» (Moholy-Nagy, 1963, pp. 64-65). En definitiva, el cubismo había apostado decididamente por la "reinterpretación" de una realidad cambiante huyendo a todas luces de la "representación retiniana» clásica, propia de una concepción tradicional del

5. Nos referimos a la obra de Cézanne catalogada como "Study of Trees", datada en torno a 1904, cuyo título alternativo es también el de "Arbres; Winding Road", $\mathrm{n}^{\circ}$ de inventario: 1998.305, en los Harvard Art Museums, Cambridge, Massachusetts. 
espacio pictórico. Porque era justo ahí, en la exactitud óptica, donde, décadas atrás, la fotografía y el cine ya habían comenzado a vaciar de sentido cualquier pretensión pictórica por atrapar la realidad de forma fidedigna. Su campo de actuación se centraría a partir de ahora en un nuevo acercamiento visual, pero ya no a través de una proyección sobre la realidad tal y como el ojo la veía, o tal y como la fotografía la registraba. Se trataría más bien de un modo particular de conocimiento basado en la fragmentación del espacio continuo. Esta nueva interpretación del referente contemplaba ahora aspectos que hasta entonces habían quedado fuera del espacio pictórico, sobre todo la inclusión de la cuarta dimensión -el tiempo- incorporándose ahora, mediante recursos diversos, al espacio bidimensional de la representación.

Años antes, entre 1882 y 1900, el fisiólogo francés Éttiene-Jules Marey, además de profesor e investigador ${ }^{6}$, inspirado por los experimentos precinematográficos de Muybridge en Estados Unidos, comenzó a trabajar en una propuesta fotográfica propia para analizar secuencialmente el movimiento humano y animal. Marey fotografió, entre otros, el vuelo de las aves, el galope de los caballos o los movimientos habituales de los seres humanos (carreras, saltos, etc). Se propuso representar diversas formas de locomoción compleja de los seres vivos registrados mediante un peculiar método fotográfico de su invención. Confeccionó un sofisticado artilugio, el "fusil fotográfico», que consistía en una cámara adaptada a un artefacto de apariencia armamentística, y que producía varias obturaciones muy rápidas y repetitivas. Acoplando el objetivo fotográfico al cañón de su singular «escopeta» y con un obturador sincronizado al gatillo de la misma, estos «disparos» se sucedían secuencialmente y de forma constante durante un corto periodo de tiempo. Marey consiguió que las instantáneas conseguidas con la luz que entraba repetidamente por el objetivo de la cámara quedasen impresionadas sobre una misma placa fotosensible en forma de imágenes secuenciales: en una cadencia de doce tomas por segundo y a una velocidad aproximada de $1 / 720$ de segundo. Con ello lograría congelar un mismo movimiento en diversas fases de ejecución (figura 3).

Figura 3. Éttiene-Jules Marey. «The Running Lion Tamer», 1886.

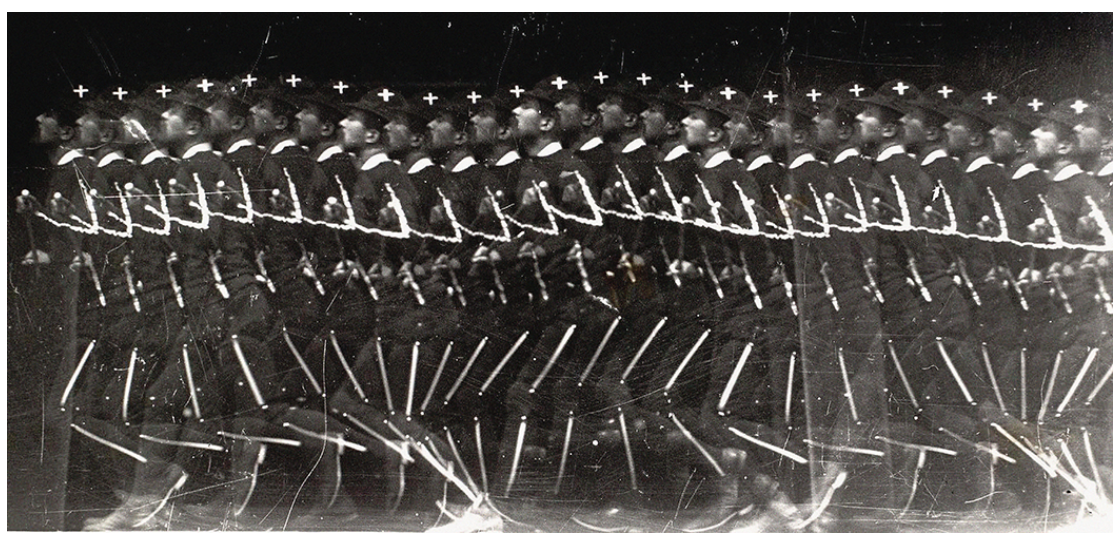

6. Marey era miembro de la Academia de París, así como profesor titular de la cátedra de Historia Natural de los Cuerpos Organizados en el Colegio de Francia. 
Esta disección fotográfica de cada movimiento permitía estudiarlo con precisión, superando así la lentitud perceptiva del ojo humano. A estos experimentos, donde el artilugio fotográfico registraba un cierto lapso de tiempo, Marey los denominó «cronofotografías» (Frizot, 1984) ${ }^{7}$. Aunque originariamente Marey no perseguía una pretensión estética, sus cronofotografías acabaron convirtiéndose en fuente de inspiración para muchos creadores que buscaban ir más allá de la imagen estática que hasta ese momento les ofrecían sus pinceles.

De esta forma, Marcel Duchamp, precursor del dadaísmo y el arte conceptual, realizaría su emblemática obra Desnudo bajando una escalera en 1912 (figura 4).

Figura 4. Marcel Duchamp. «Nu descendant un escalier», 1912

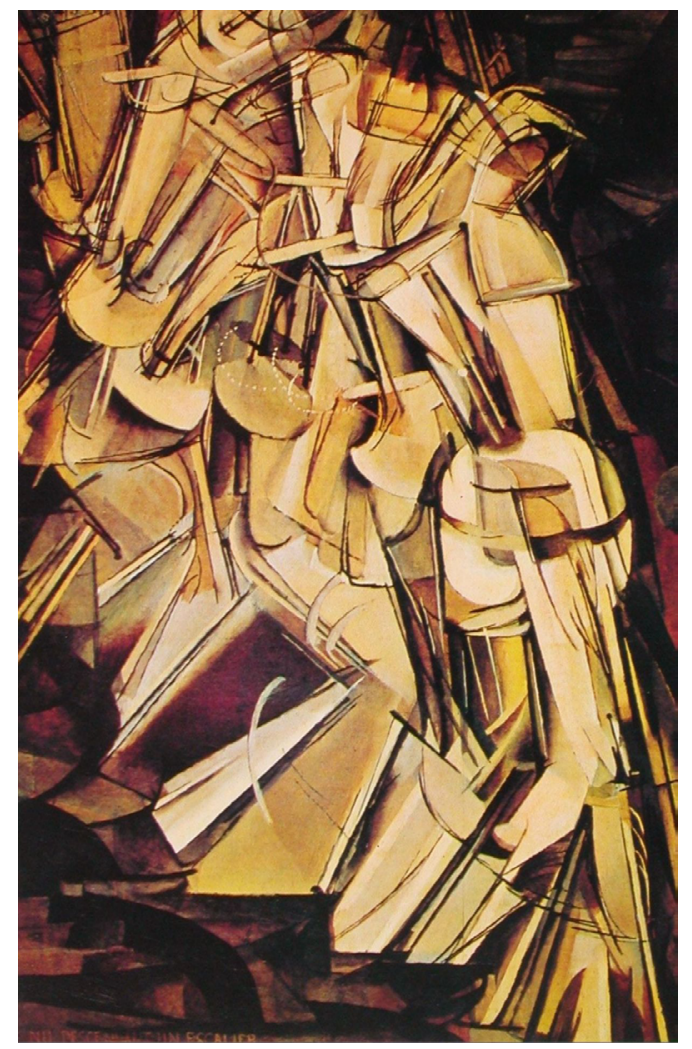

En este cuadro pueden adivinarse los rasgos esquemáticos de una figura humana, cuya composición secuencial parece recrear el tiempo en nuestra retina. En una entrevista concedida a Pierre Cabanne, el propio Duchamp admitiría sin pudor que

7. En 1889, el propio Marey ofreció la primera representación histórica de una "película», seis años antes de la exhibición del cinematógrafo de los hermanos Lumière.

Cfr. Frizot, Michael (1984), «Le temps contitué. Récit chronophotographique avec arrêts sur image», en el libro-catálogo Éttiene-Jules Marey, editado por el Centre National de la Photograhie de París, París: Photopoche. 
su fuente de inspiración se encontraba precisamente en aquellas cronofotografías de Marey que, al parecer, le habían producido una honda impresión (figura 5):

«Pierre Cabanne. - ¿No hay en el $N u$ descendatn un escalier una influencia cinematográfica?

Marcel Duchamp. - Evidentemente. Es cosa de Marey...

P.C.- La cronofotografía.

M.D.- Sí. Yo había visto en la ilustración de un libro de Marey cómo marcaba a las personas que practican esgrima, o los caballos al galope, con un sistema de punteado que delimitaba los movimientos diversos. De este modo explicaba la idea de paralelismo elemental. Ello tiene un aspecto muy presuntuoso como fórmula, pero es muy divertido.

Eso es lo que me dio la idea de la ejecución del $N u$ descendatn un escalier. Utilicé un poco de ese procedimiento en el esbozo, pero primordialmente, en el último estadio del cuadro. Ello debió ocurrir de un modo definitivo entre diciembre y enero de 1912» (Cabanne, 1967, pp. 49-50).

Figura 5. Éttiene-Jules Marey. «Saut d'une chaise d'un homme en maillot noir, chronophotographie géométrique partielle», 1884

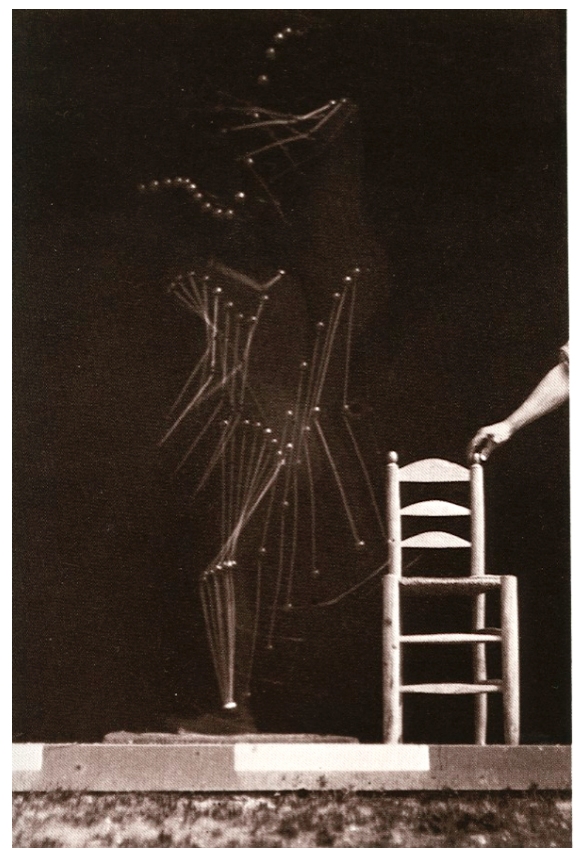

Fraccionar el tiempo, seccionarlo en fases en esta obra de Duchamp, suponía algo más que una reflexión acerca de la lógica temporal inferida únicamente desde la propia pintura. La influencia tecnológica que la cámara había provocado resultaba ya incuestionable para buena parte de las formas artísticas de la época. Durante las primeras décadas del s. XX, la obsesión por interpretar el movimiento y del flujo temporal se había convertido, a todas luces, en una cuestión estética y artística, y no solo en una preocupación puramente científica. 
Por esas mismas fechas, en Italia, un grupo de jóvenes artistas, bajo los auspicios de su ideólogo, el poeta Filippo Tommaso Marinetti, darían forma a un nuevo movimiento de vanguardia denominado Futurismo. Prueba fehaciente de que el virus del progreso y el ritmo frenético impuesto por la tecnología había calado profundamente en la estética pictórica de inicios del XX, lo constituye el innovador concepto de belleza plasmado por los futuristas en su manifiesto fundacional:

«Nosotros afirmamos que la magnificencia del mundo se ha enriquecido con una belleza nueva: la belleza de la velocidad. Un automóvil de carreras con su capó adornado de gruesos tubos semejantes a serpientes de aliento explosivo..., un automóvil rugiente que parece correr sobre la metralla es más bello que la Victoria de Samotracia" (Marinetti, 1909).

A partir de entonces, artistas futuristas, como Giacomo Balla, Gino Severini, Luigi Russolo, Carrà o Umberto Boccioni, se entregaron a una nueva causa para equiparar su arte al éxito del cine, aunque mediante un tipo de imágenes fijas que, sin embargo, eran capaces de evocar una secuencia temporal y dinámica, ya fuese a través de la pintura o la escultura. De este modo, obras tan emblemáticas, como la escultura de Boccioni titulada Formas únicas de continuidad en el espacio (1913) (figura 6), o diversas composiciones pictóricas de Severini o Balla (como Dinamismo de un perro con correa, de 1912) (figura 7) supusieron un arma arrojadiza contra la visión aburguesada del momento, al alumbrar un nuevo modo de relatar el mundo en torno.

Figura 6. Umberto Boccioni. "Forme uniche della continuità nello spazio», 1913.

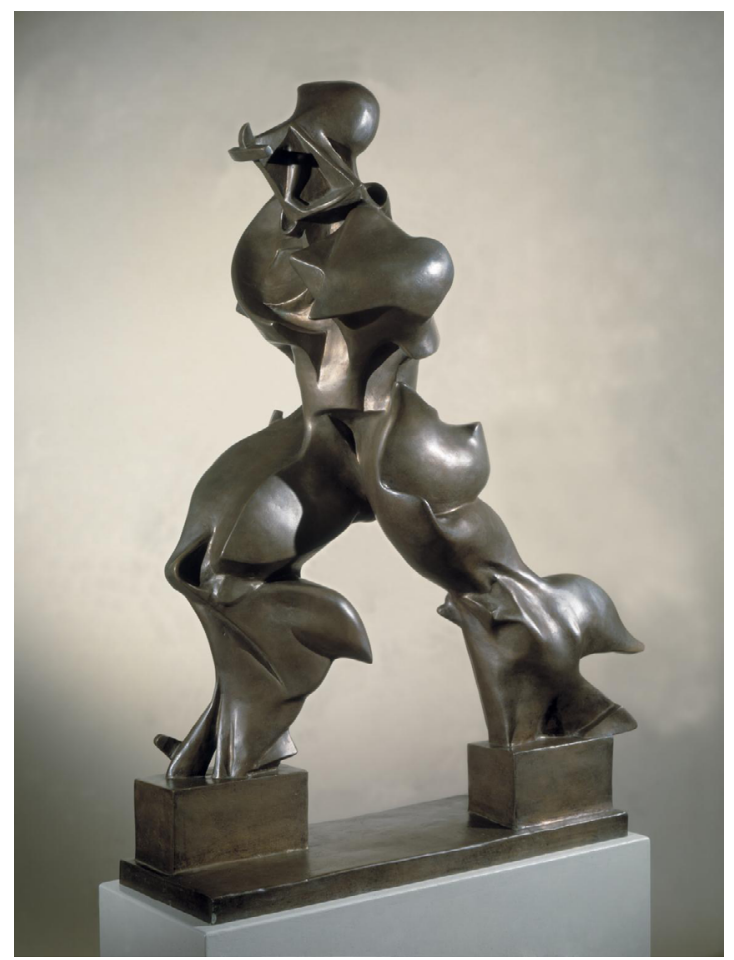


Figura 7. Giacomo Balla. «Dinamismo di un cane al guinzaglio», 1912

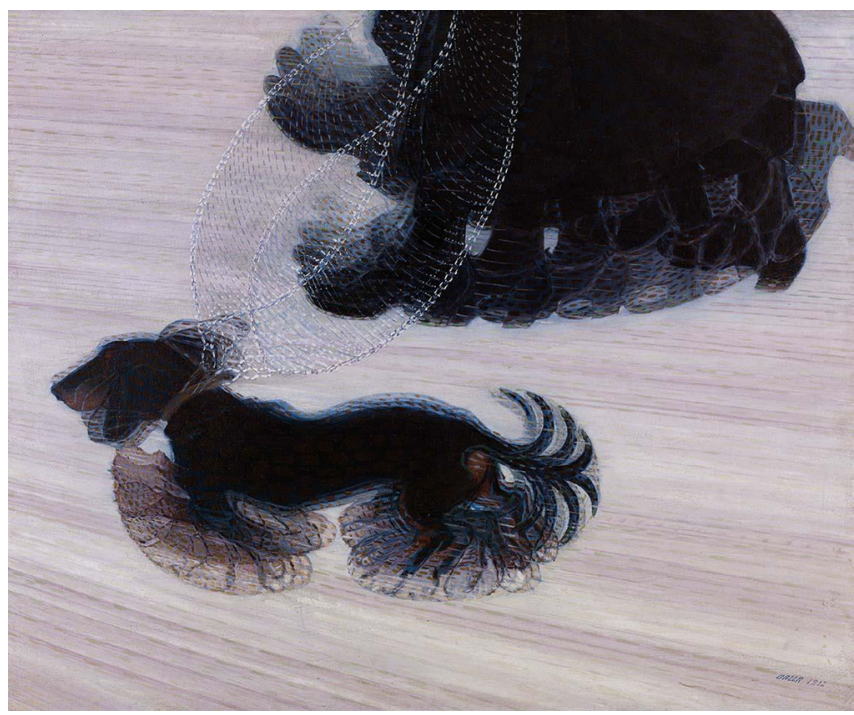

Sin embargo, el estallido de la Primera Guerra Mundial truncaría muchas de las aspiraciones de los futuristas (incluso también algunas vidas) y nuevas propuestas, desgajadas del futurismo y el cubismo, se concretarían en movimientos como el Vorticismo o el Orfismo. Estas nuevas corrientes pictóricas ya no tratarían de representar formas concretas, sino más bien ritmos visuales de luz y estados abstractos de movimiento puro, mediante sensaciones ópticas de vértigo y aceleración, como podemos apreciar en muchas obras de Kupka o de Robert y Sonia Delanuy (figura 8), entre otros.

Figura 8. Sonia Delanuy. «Prismes électriques», 1914

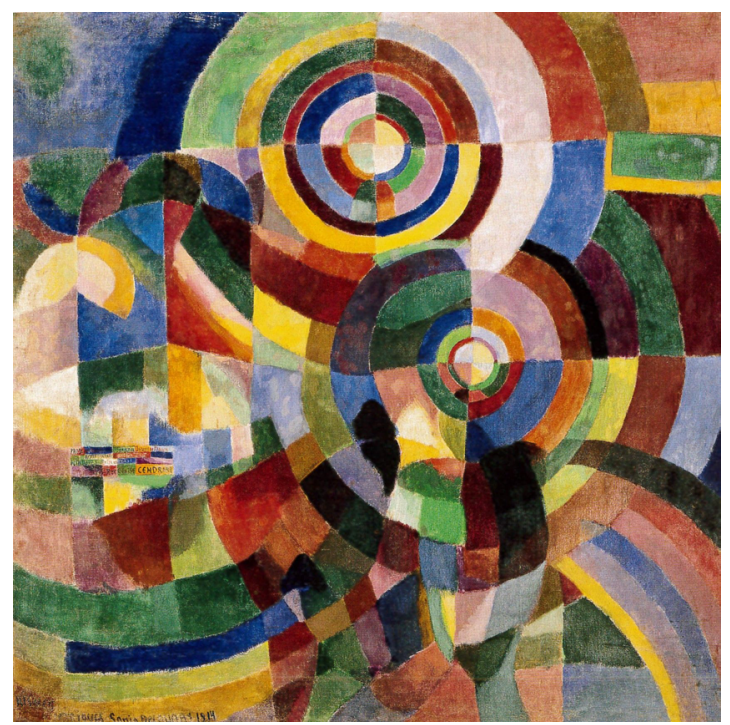


Sin embargo, y antes del fin de la Gran Guerra, los futuristas renegaron de sus principales fuentes de inspiración (como la cronofotografía misma). Este poner tierra por medio de los pintores y escultores futuristas frente a todo aquello que sonase a imagen mecánica no era más que una defensa férrea de su condición de creadores "puros», sin «muletas» tecnológicas, que pudiese mermar su aura de artistas. ¿Deseos de matar al padre inspirador? Quizás. No en vano, los futuristas habían sido duramente criticados por lo que algunos teóricos de la época tildaron como una excesiva presencia cinematográfica y cronofotográfica en su pintura. En respuesta a estos ataques, Boccioni, uno de los mejores exponentes del Futurismo, se defendía en una carta del siguiente modo:

«Siempre hemos rechazado con asco y desdén incluso la más lejana vinculación con la fotografía, porque se encuentra fuera de los límites del arte. La fotografía tiene valor en la medida en que, reproduciendo los objetos e imitando objetivamente, ha conseguido gracias a su perfección, liberar a los artistas del peso de reproducir la realidad con precisión» (Boccioni, 1913).

Sin embargo, la auténtica razón de esta reacción iracunda de Boccioni contra la fotografía parece mucho más prosaica: en el fondo se trataba de una cuestión de celos. La imagen mecánica, ya fuese fotográfica o cinematográfica, captaba el movimiento mucho mejor y más rápido que cualquier método pictórico planteado por estos «artistas puros", por muy bien que intentasen plasmar sus propuestas dinámicas de materia pictórica sobre el espacio. En cierto modo, un soterrado complejo de inferioridad se acabaría adueñando de los futuristas frente a los procesos tecnológicos de la imagen audiovisual que ellos mismos habían propugnado originariamente mediante el ensalzamiento estético de los productos propios del progreso industrial. Aunque la belleza de la máquina fuese una de sus máximas fundacionales, sin embargo, los futuristas no supieron (o no quisieron) asimilar que buena parte de su corpus estético se cimentaba sobre productos generados por una de esas máquinas: la cámara, que permitiría articular nuevas formas de representación del movimiento y el tiempo a través de los revolucionarios modos "cronofotográficos» de $\mathrm{Marey}^{8}$.

Mientras tanto, durante aquellas primeras décadas del siglo XX, el cine ya había tomado clara ventaja a la hora de formular con éxito su propio lenguaje narrativo. Su particular poderío técnico para construir relatos visuales en el espacio y el tiempo, cogiendo de aquí y de allá (de la literatura y de las artes visuales, del teatro y de la escenografía), acabaría por dinamitar los cánones tradicionales de la representación plástica. Como caballo de Atila, el lenguaje cinematográfico trituraba los viejos modelos de representación visual y cimentaba sus nuevas propuestas discursivas "galopando" a lomos del montaje. Muchos artistas plásticos de vanguardia intentaron emular las nuevas propuestas narrativas del cine, mediante la yuxtaposición de fragmentos separados, en una especie "corta y pega» de imágenes que -conformando una nueva gramática visual- eran descontextualizadas de su origen y vueltas a recontex-

8. De hecho, hubo dos fotógrafos representados en el movimiento futurista: los hermanos Anton Giulio y Arturo Bragaglia. Pero nunca encajaron del todo bien en él. El propio Boccioni escribió en la revista futurista Lacerba condenando el "fotodinamismo" de los Bragaglia, que consistía en una suerte cronofotografía artística. Tras unos años de tensiones con diversos miembros del Futurismo, los Bragaglia serían expulsados sin contemplaciones del movimiento. 
tualizar ideológica y sintácticamente sobre la nueva composición artística. Este nuevo modus operandi cobraría forma mediante el fotomontaje y el collage, emulando sobre un soporte bidimensional y fijo lo que el montaje cinematográfico ya venía haciendo con sus "fragmentos» de tiempo. Particularmente activos en estas lides fueron los creadores dadaístas, constructivistas y surrealistas. En algunos casos, más que obras de arte al uso, sus fotomontajes sirvieron como armas ideológicas y alimento diario de portadas para algunos medios de comunicación progresistas, como es el caso de John Heartfield en Alemania (figura 9) con la revista de izquierdas $A I Z$ o de Alexander Rodchenko en la Unión Soviética (figura 10) con revistas rupturistas como Novi Lef. Esta técnica híbrida del foto collage o montaje fotográfico se erigiría desde entonces en el caballo de batalla con el que las artes plásticas podían rivalizar con esas otras «artes del tiempo" propias de la tecnología audiovisual.

Figura 9. John Heartfield. Fotomontaje «Reservations: Jews Driven like Cattle», 1939

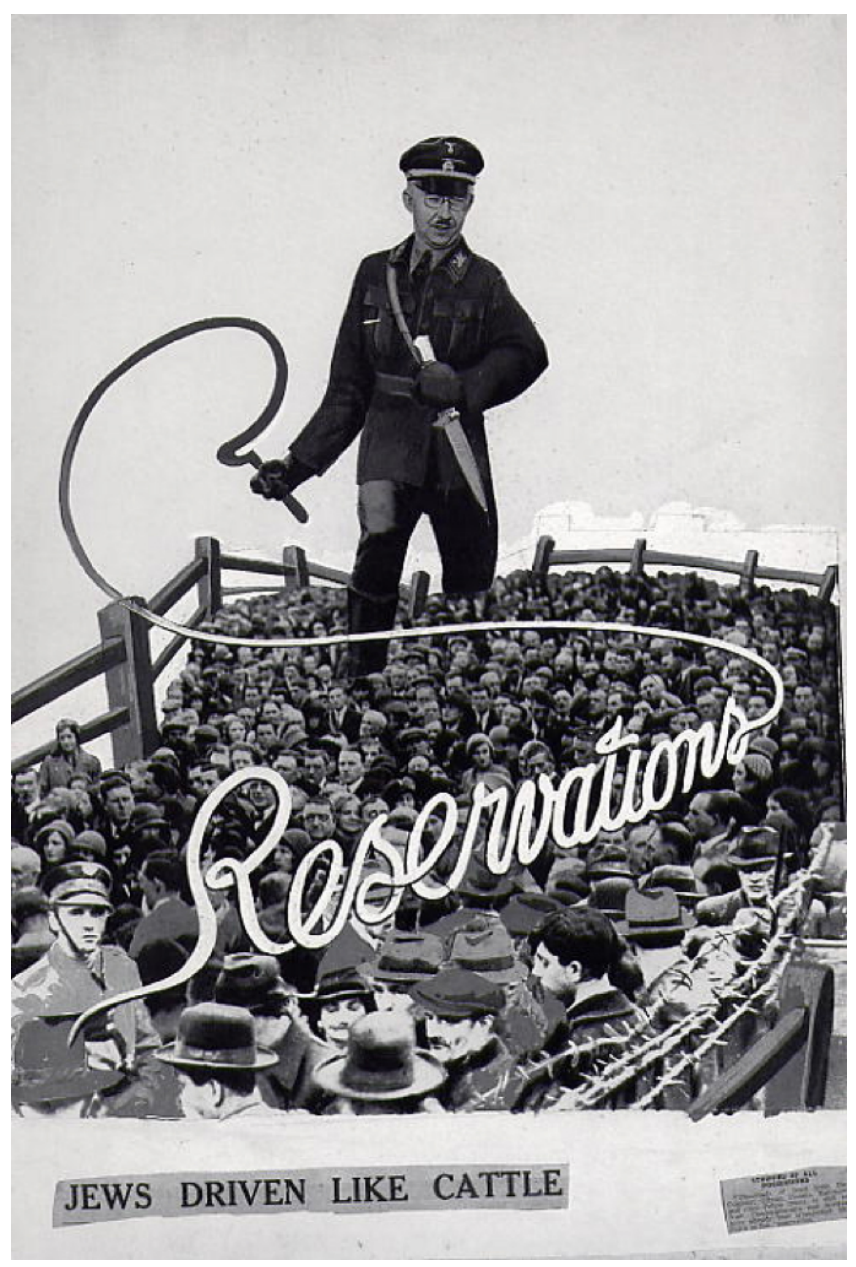


Figura 10. Alexander Rodchenko. Fotomontaje para el poema «Pro Eto» (Sobre esto) de Vladimir Mayakovsky, 1923.

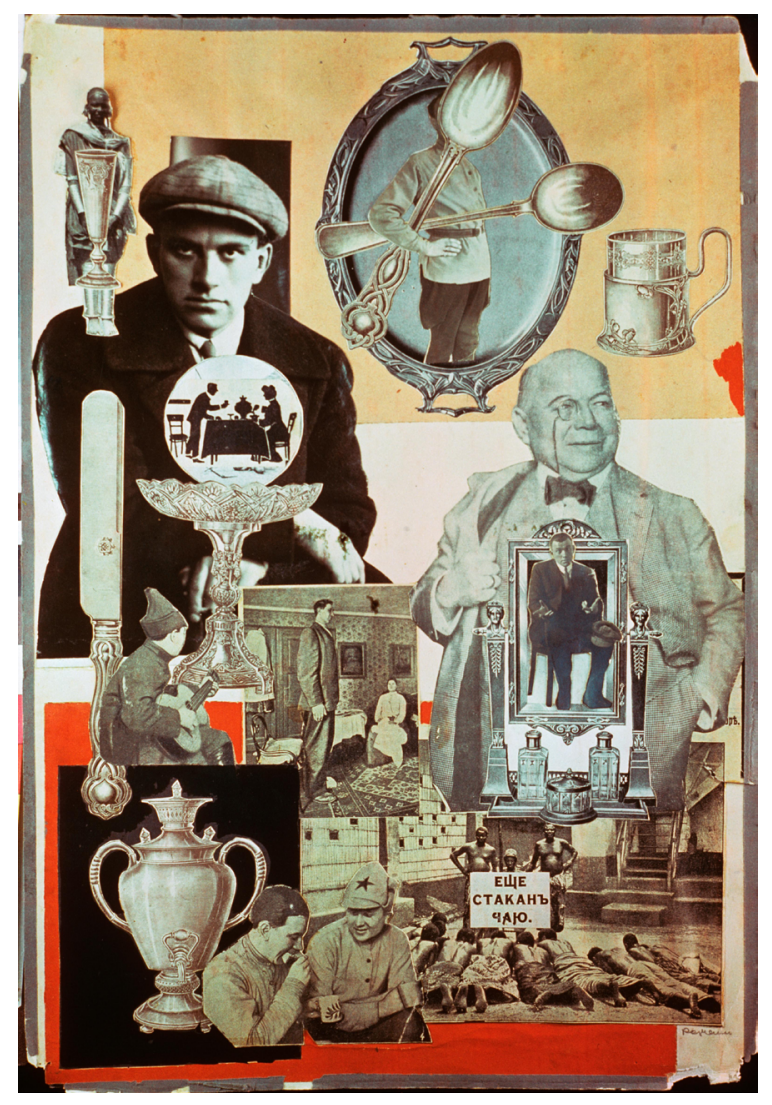

A partir de la segunda mitad del siglo XX, tanto la fotografía documental, por un lado (centrada desde los 50 fundamentalmente en el reportaje humanista), como la pintura, por otro (mediante sus derivas abstraccionistas tras las vanguardias) parecían haber encontrado su propia manera de expresarse sin demasiados préstamos lingüísticos de uno u otro lado. De algún modo, cada una de ellas estaba buscando su propia especificidad discursiva tras un siglo de mutuas influencias y contaminaciones. Como postulara Clement Greenberg, defensor teórico a la sazón de la pintura abstracta norteamericana, cada medio debía encontrar -mirándose hacia sí mismo como lenguaje- su propia manera de contar las realidades externas o internas que preocupaban a los artistas contemporáneos. El discurso se fue volviendo así claramente metalingüístico: lo que se estaba defendiendo era una forma de pintura hablando únicamente de sí misma, cuestionándose a sí misma. Los temas y géneros pictóricos tradicionales eran ya meras excusas para un arte que estaba volviéndose cada vez más autorreferencial.

«La esencia del movimiento moderno consiste, a mi modo de ver, en el uso del método característico de una disciplina para criticar esa misma disciplina [...] Lo que debía mostrarse y hacerse explícito era no sólo aquello exclusivo e irreductible del arte en general, sino también de cada arte particular. Cada arte debía determinar, mediante los 
mecanismos que le fueran propios, sus efectos peculiares y expresivos... Enseguida se puso de manifiesto que el ámbito único y propio de competencia de cada arte coincidía con todo aquello que era exclusivo de la naturaleza de su medio» (Greenberg, 1960).

Sin embargo, esta tendencia no podía durar eternamente. Las confluencias y contaminaciones mutuas entre pintura y fotografía habían sido demasiado poderosas durante este último siglo y medio como para seguir ignorándose recíprocamente durante demasiado tiempo. Al comparar, por ejemplo, algunas propuestas fotográficas del último cuarto del siglo XX (que cimentaron sus narrativas visuales en la puesta en escena) con las del arte tradicional, comprobaremos, por ejemplo, cómo la llamada "Pintura de Historia» del XVII y XVIII ya había articulado tempranamente -y con cierto éxito- un método narrativo propio, lo que influiría de forma determinante sobre el resto de las artes, incluyendo por supuesto esta llamada fotografía "construida» o staged photography. En origen, la pintura de historia se limitaba a componer una única escena en su momento de mayor clímax (una especie de foto fija) para dar cuenta de un suceso histórico concreto. Sin embargo, esta estrategia carecía de herramientas para plasmar el relato completo y, por tanto, se mostraba estéril para referir dicho acontecimiento prolongado en el tiempo. La llegada de la industria del cine en el XX vendría a sacar tanto a la pintura de Historia como a la fotografía pictorialista de ese atolladero.

De cualquier modo, el malestar de la pintura con la plasmación del tiempo y su narrativa asociada no era un problema nuevo. Ya en el siglo XVIII, el filósofo Gotthold Efraim Lessing había evidenciado la futilidad del arte plástico a la hora de narrar episodios extensos, a diferencia de lo que ocurría con el arte literario y poético. En su obra, Laocoonte o los límites de la pintura y la poesía (1766), Lessing definiría a las artes plásticas como «artes del espacio», mientras que la poesía debía ser calificada, según él, como un "arte del tiempo». Contra el aforismo largamente asumido del «Ut Pictura Poesis" (Como la pintura, así es la poesía») del poeta latino Horacio (siglo I A.C), Lessing argumentaría que estas dos disciplinas -consideradas hasta entonces "artes hermanas»- no debían equipararse entre sí ni en funciones ni en métodos de representación. Aunque durante mucho tiempo ambas artes (poesía y pintura) se habían consagrado a la descripción de las cosas naturales, no es menos cierto que sus enfoques sobre los hechos relatados distaban enormemente.

Lessing sostenía que, debido a su incapacidad manifiesta para articular narraciones temporales, la pintura, el dibujo o la escultura sólo podían aspirar a representar el instante "más pregnante» del acontecimiento descrito. Centradas así las artes plásticas en un solo "momento decisivo" del relato, el artista debía escoger la mejor forma para materializarlo (mediante tensión, gestualidad, composición...), de modo que esa escena fija permitiera intuir lo sucedido un momento antes y vislumbrar también lo que estaba a punto de suceder después (Lessing, 1766).

Durante algún tiempo, la autoproclamada "fotografía artística» (del último tercio del XIX), sustanciada en el pictorialismo fotográfico, no sólo aspiró a emular los acabados pictóricos, sino también sus mismas estrategias narrativas. De este modo, muchos fotógrafos pictorialistas 9 se afanaron en "componer" sofisticadas escenas,

9. Los pictorialistas más célebres del s. XIX, en lo tocante a la llamada Staged Photography (o foto construida), fueron Henry Peach Robinson y Oscar Gustav Rejlander; aunque la fotógrafa Julia Margaret Cameron, consumada retratista, también se aplicó a la construcción de escenas basadas en relatos legendarios, como la vida y muerte del Rey Arturo (1874), por ejemplo. 
bien mediante complejos tableaux vivants preparados de un modo artificioso y teatral, o bien a través de elaborados montajes fotográficos compuestos en el cuarto oscuro por varios negativos que simulasen una escena final unitaria y sin parches (figura 11).

Figura 11. Henry Peach Robinson. «Fading away», 1858.

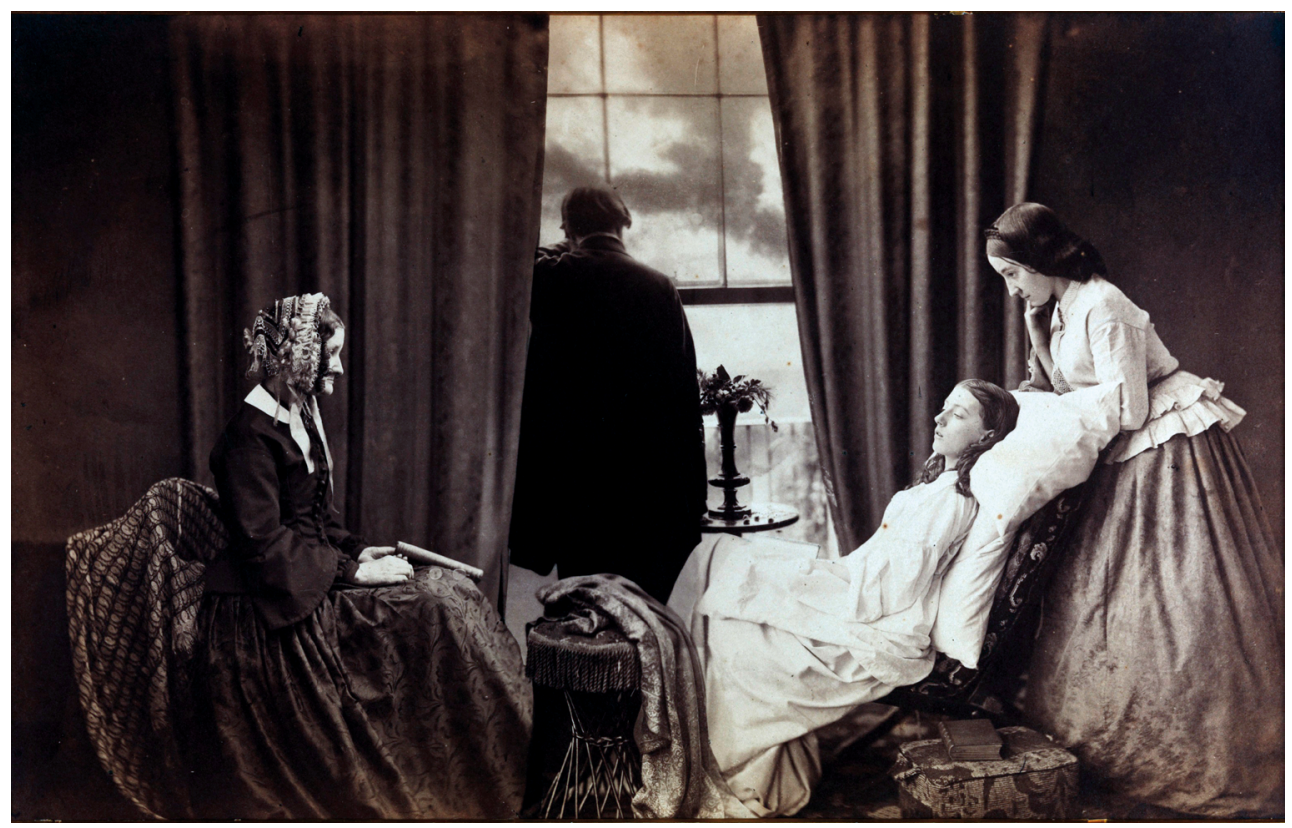

Inspiradas por aquella tradición pictorialista del XIX, algunas propuestas fotográficas contemporáneas del último cuarto del s. XX se han centrado en ese mismo tipo de "puesta en escena", aunque ahora desde un posicionamiento netamente fotográfico y postcinemático que ya no resulta tan deudor de la pintura como entonces. Tal es el caso de proyectos tan aplaudidos como las enigmáticas foto secuencias de ficción de Duane Michals, los Untitled Film Stills de Cindy Sherman de principios de los ochenta (figura 12), los falsos «instantes decisivos» de Jeff Wall en los noventa -compuestos digitalmente desde un posicionamiento foto conceptual- (figura 13), o las apabullantes puestas en escena (mediante luz, actores y cuidados decorados) de Gregory Crewdson de finales del XX y principios del XXI (definidas por él mismo como "películas de un solo fotograma») (figura 14). Sin embargo, ninguna de estas propuestas fotográficas ha podido soslayar los condicionantes narrativos apuntados por Lessing para las artes plásticas. En todo caso, se han acercado con astucia a una especie de «tiempo suspendido» en un relato más propio del cine, donde lo inquietante (al sugerir lo que está a punto de suceder en la escena) se muestra aquí con todo su esplendor. 
JOSÉ GÓMEZ-ISLA

NARRATIVAS DE IDA Y VUELTA: APROPIACIONES, INFLUENCIAS Y CONTAMINACIONES MUTUAS ENTRE PINTURA, FOTOGRAFÍA Y CINE

Figura 12. Cindy Sherman. «Untitled Film Stills \#49», 1979

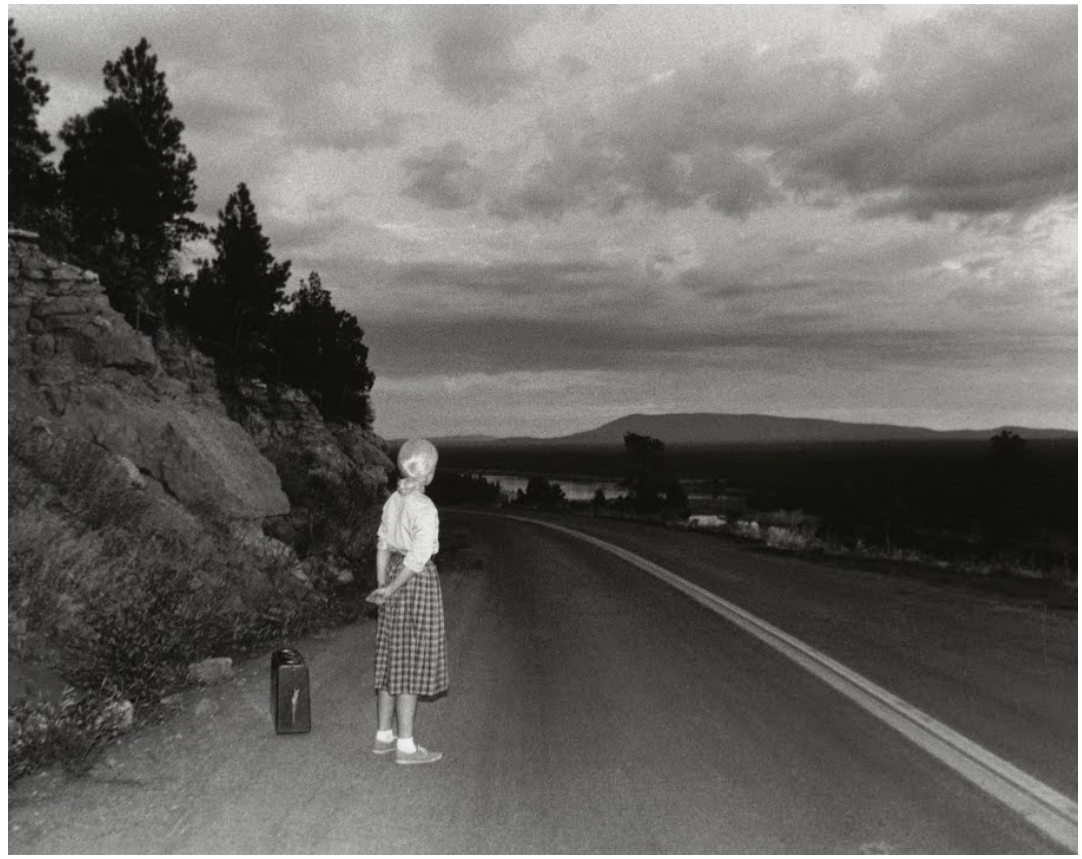

Figura 13. Jeff Wall. «The Stumbling Block», 1991

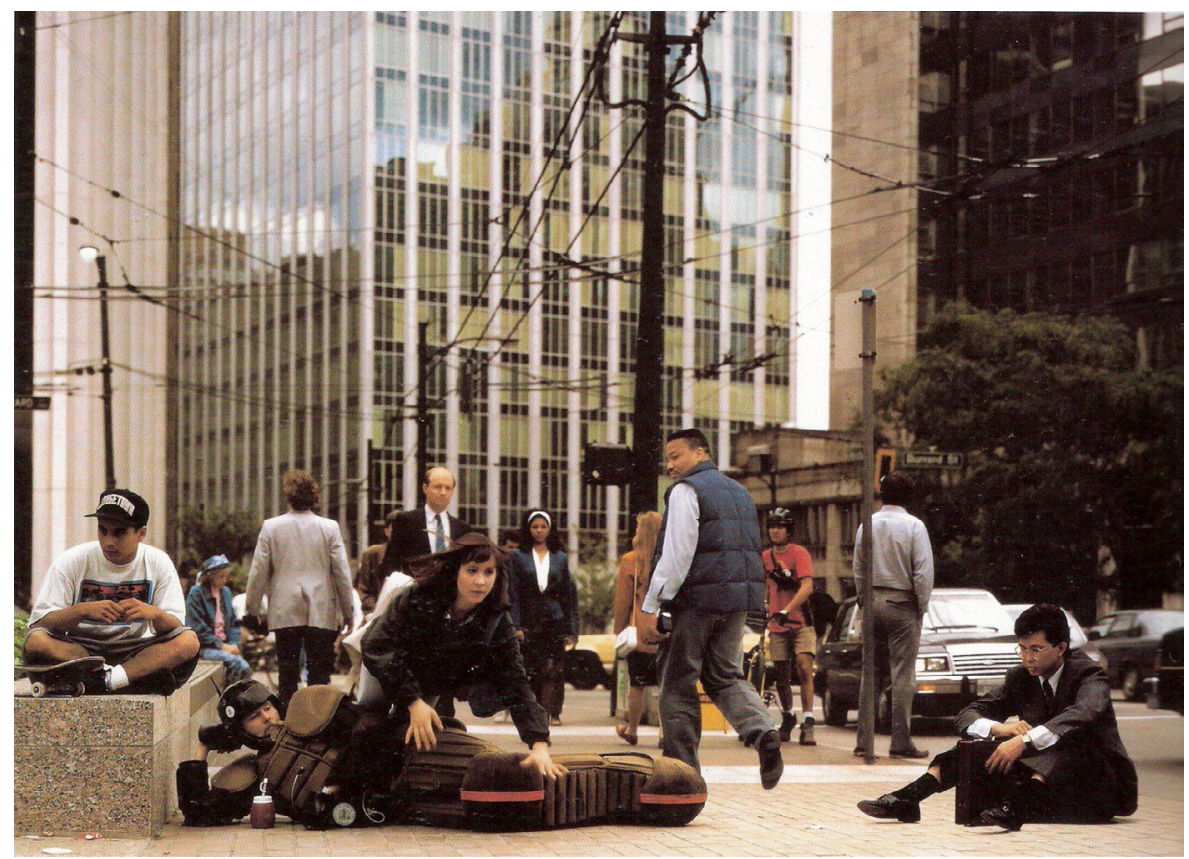




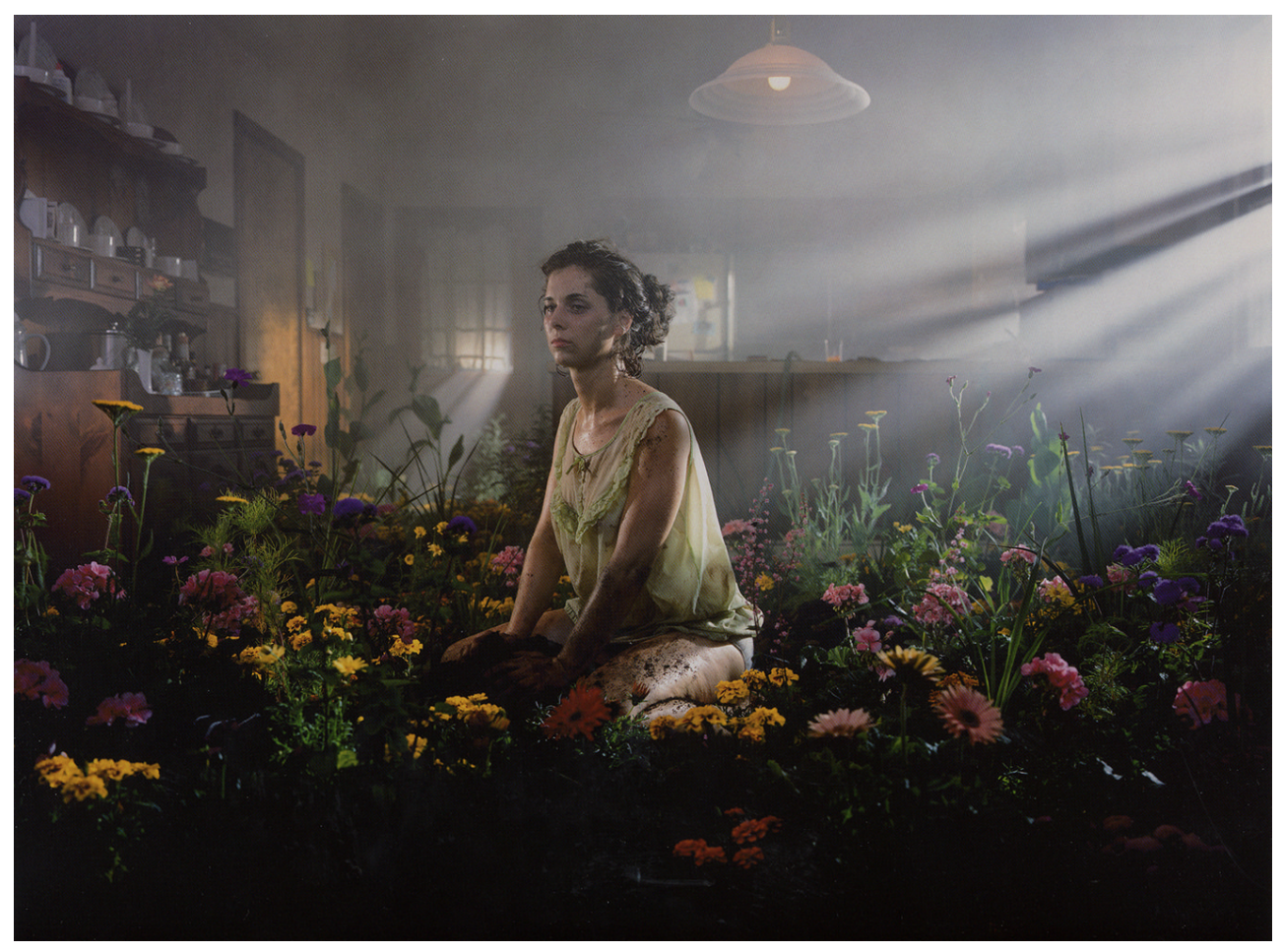

Otras propuestas más recientes, a caballo entre el fotoconceptualismo y el fotodocumentalismo, han recurrido a la "serie fotográfica» como método recurrente de trabajo. Mediante la disposición cronológica de sus polípticos fotográficos, ordenando secuencialmente sus imágenes, estos autores han conseguido plasmar con rotundidad ciertos conceptos temporales heredados directamente del modelo constructivo del álbum de familia.

Con esta metodología, algunos de estos creadores actuales, centrados esencialmente en el retrato frontal y sin artificios, plantean en sus series una secuenciación programática de sus personajes a lo largo del tiempo. Buena parte de estos fotógrafos se van a volcar en los aspectos emocionales y sobrecogedores generados por el cambio, la metamorfosis y los efectos visibles que el devenir temporal produce sobre esos rostros retratados. Sus obras no nos hablan solo del curso natural de la existencia, sino también de las distintas maneras de afrontarla, de adaptarse y de relacionarse con ella mediante la transformación física de los protagonistas de cada serie. Exponentes de esta corriente fotográfica que, a partir de los años setenta del XX empezaría a utilizar el retrato transtemporal como estrategia discursiva, son autores como el norteamericano Nicholas Nixon, con su serie The Brown Sisters (1975-2017) (figura 15), la holandesa Rineke Dijkstra (en amplias series realizadas a partir de los años noventa) (figura 16) o el fotógrafo catalán Pere Formiguera, con su proyecto Cronos (1990-2011) (figura 17). 
Figura 15. Nicholas Nixon, «The Brown Sisters», 1975-2017. (Fragmento).

Colecciones Fundación MAPFRE. Copyright: Jesús Antón

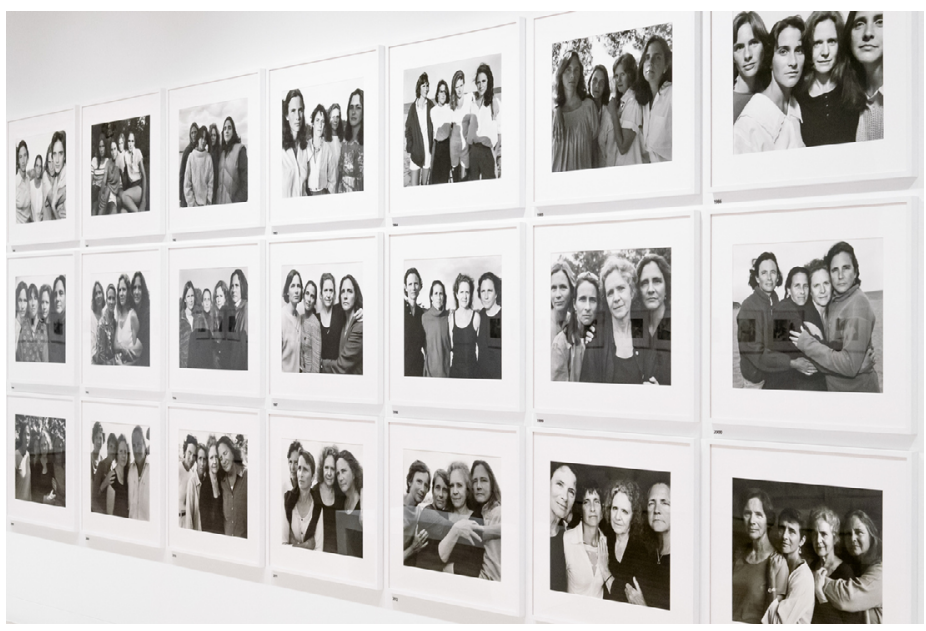

Figura 16. Rineke Dijkstra. «Almerisa», Países Bajos. Imágenes fechadas entre el 24 de marzo de 1994 y el 25 de junio de 2003
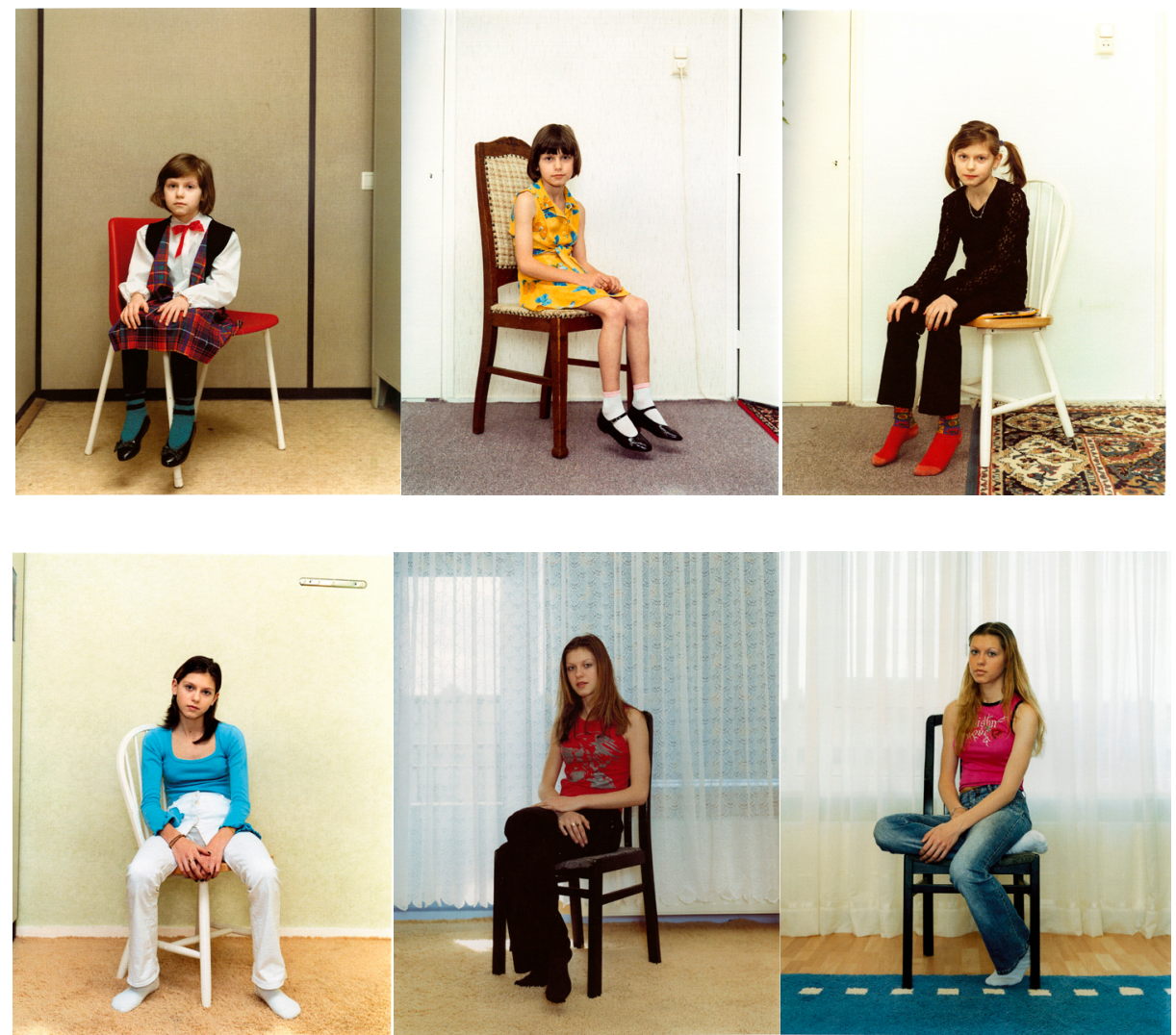
Figura 17. Pere Formiguera. Detalle del proyecto «Cronos», 1990-2011

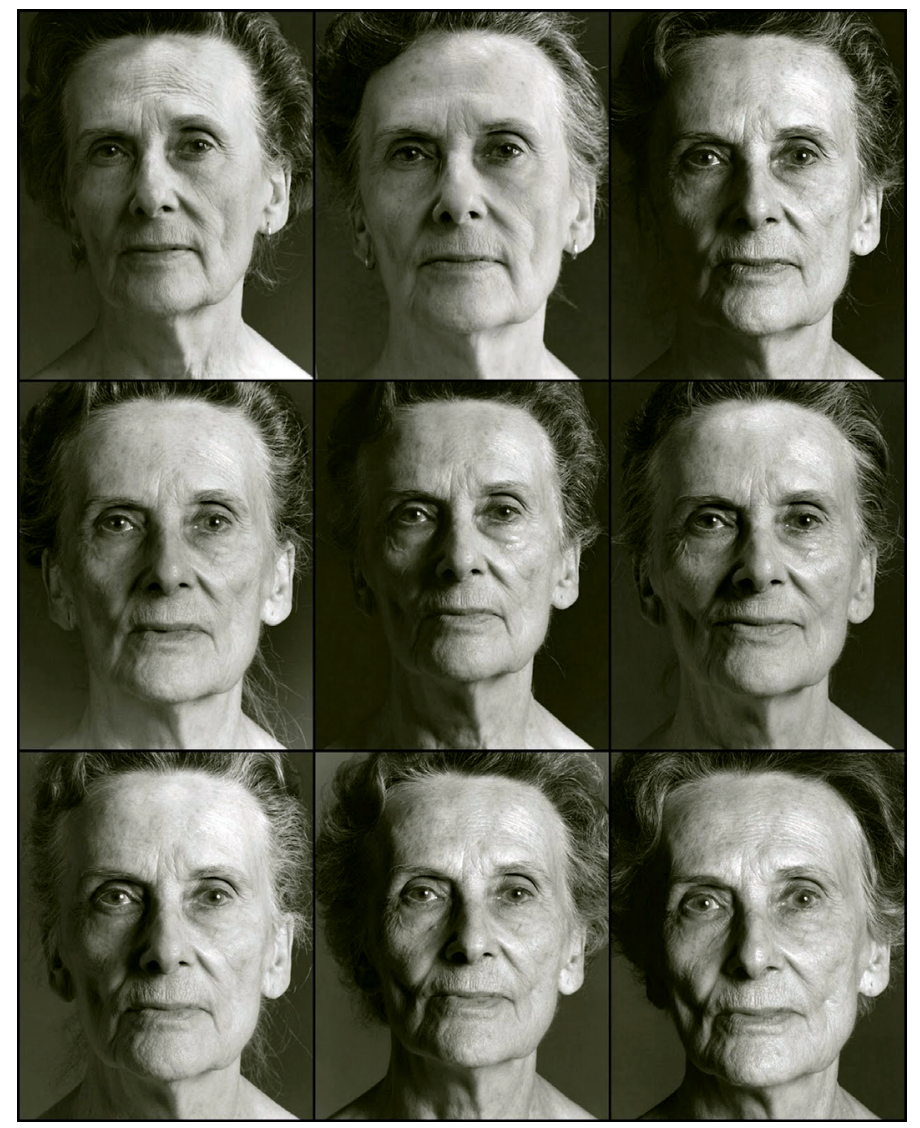

De igual modo, la secuenciación fotográfica y su «flujo temporal visible» también ha sido abordado por otros muchos artistas conceptuales que, sin ser fotógrafos profesionales, se van a servir de la fotografía para materializar sus proyectos. En ocasiones las instantáneas que utilizan no son ni siquiera suyas. Algunos de ellos recopilan -con afán archivístico y, sobre todo, apropiacionista-imágenes cotidianas, ya se trate de fotos de aficionado o bien procedan de los medios de comunicación. Con una estética cercana al archivo documental, estos autores se afanan, con meticulosidad exquisita, en la recontextualización de imágenes dispuestas en un determinado orden, a fin de producir un aparato visual crítico y político. Mediante el ensamblaje de ciertas fotografías reapropiadas -o, mediante performances documentadas a lo largo del tiempo realizadas exclusivamente para la cámara-, estos artistas consiguen transmitirnos, con poderosa eficacia, conceptos intangibles sobre el transcurso de nuestra existencia; unos conceptos que los propios autores cargarán ideológicamente de significado. Este es el caso de artistas, como los españoles Ignasi Aballí, Esther Ferrer (figura 18) o Bernardí Roig (figura 19), por poner sólo algunos ejemplos. Con sus obras seriadas, en forma de secuencias mudas, estos autores van a lanzar preguntas al propio medio fotográfico, en tanto que artefacto comunicativo, acerca de su capacidad para construir con solvencia un determinado acontecimiento narrativo. 
Figura 18. Esther Ferrer. Autorretrato en el tiempo, de la serie «El Libro de las Cabezas», 1981-2009. Fragmento de la instalación compuesta por 36 imágenes. Museo de Arte Contemporáneo de Castilla y León (MUSAC)

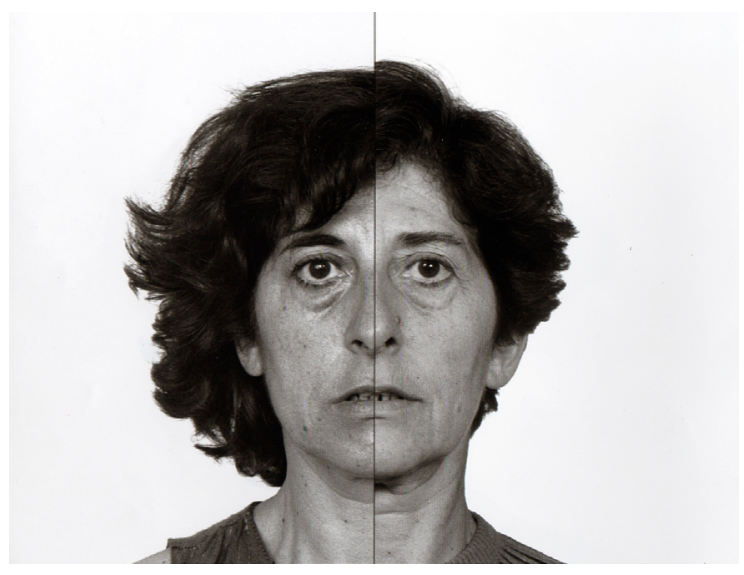

Figura 19. Bernardí Roig. Fragmento de la obra «Naufragio del rostro» (2013-2014), extraído del libro del mismo título, 300 ejemplares numerados y firmados.
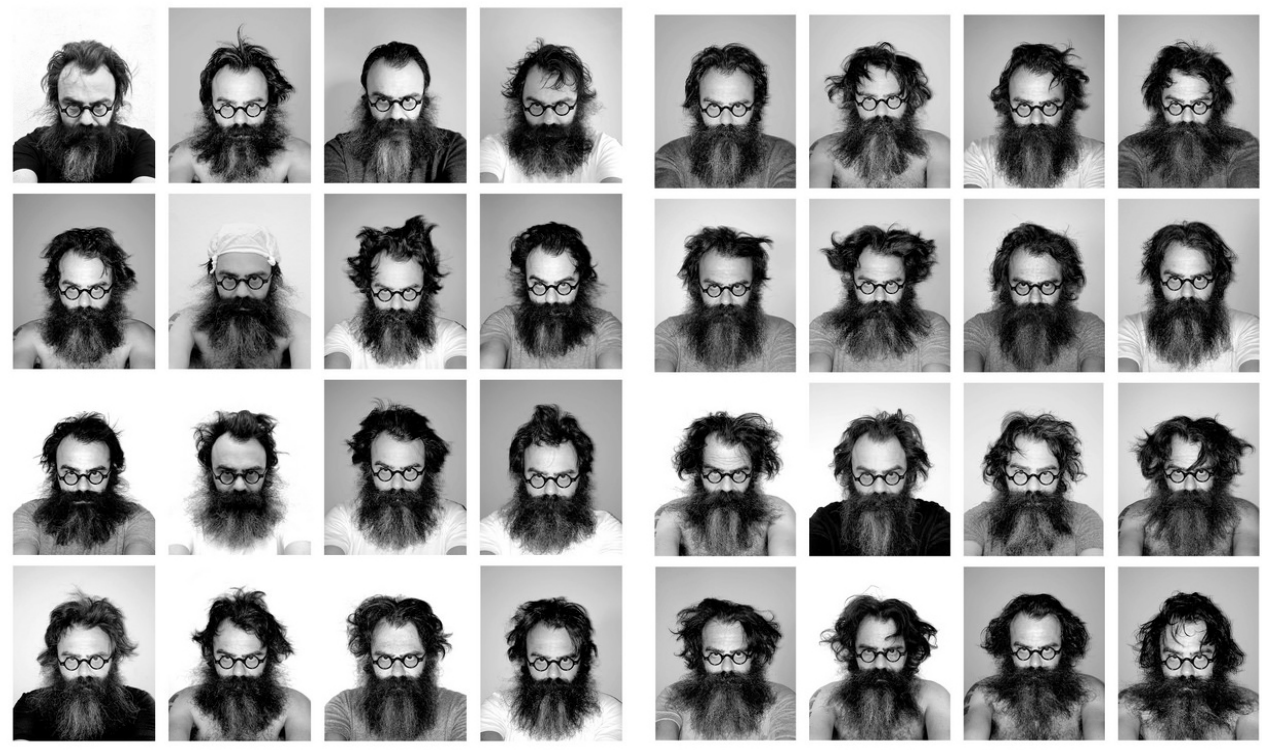

De este modo reflexionan, a su vez, sobre las estrategias metalingüísticas contradictorias que se generan en cualquier propuesta fotográfica que quiera convertirse en un relato sobre el tiempo: para narrar un fluir temporal convincente, la secuencia debe servirse paradójicamente de "fotos fijas» que niegan precisamente cualquier posible temporalidad, cualquier duración interna. Las elipsis temporales que producimos entre foto y foto no serán más que construcciones culturales que se alejan de nuestra 
percepción directa de las cosas. Estas obras sólo adquieren sentido para nosotros al tomar distancia de la realidad. Por tanto, sus series funcionan como espacios simbólicos que llenamos con una semántica y una interpretación apropiadas.

Evidentemente, sobre todas estas propuestas de finales del siglo XX (tanto pictóricas como fotográficas) sobrevuela inevitablemente la narrativa del cine. La capacidad del montaje cinematográfico para relatar y resolver con absoluta solvencia cualquier acontecimiento -desplegado en el espacio y en el tiempo- es abrumadora, sobre todo, si la comparamos con cualquier secuencia de imágenes fijas, y mudas, colocadas de forma simultánea y contigua. Sin embargo, a estos artistas conceptuales no les interesa ya especialmente la restitución temporal directa que propone el cine convencional. Si se sirven de la imagen seriada -a través de la secuencia de instantáneas y el montaje fotográfico-, es para generar un espacio discursivo sobre el que reflexionar y cuestionar las propias formas de construcción del relato visual al uso, y no tanto como medio para restituir irreflexivamente el continuum temporal de nuestra existencia cotidiana.

Para concluir, esbozaremos aquí una última pincelada que viene a reforzar todavía más la tesis sostenida sobre ese carácter móvil y en constante transformación de las instituciones y estructuras de poder que se sirven de medios como la fotografía y el cine. La aparición de la web 2.0 y los nuevos entornos multimedia ha venido a problematizar aún más el régimen de la visualidad con el cambio de paradigma que las tecnologías digitales han protagonizado desde el último cuarto del siglo XX. Muchos de los medios visuales que habían venido funcionando de forma autónoma y separada van a confluir ahora sobre este nuevo soporte digital, lo que les obligará a reformularse una vez más dentro del actual contexto cultural, ideológico, tecnológico y mediático. Como asegura Lev Manovich, «la informatización de la cultura no conduce sólo al surgimiento de nuevas formas culturales, como los videojuegos y los mundos virtuales, sino que redefine las que ya existían, como la fotografía y el cine» (Manovich, 2005, p. 52).

De igual modo, los entornos multimedia y las redes sociales también deben ser reconsiderados a la luz de esos viejos medios sobre los que se apoyan, a los que aglutinan y reformulan, y de los que se nutren también constantemente. Por esa razón, en lugar de como «nuevo medio» dominante, deberíamos entender la Web más bien como un "medio de medios" o, si se nos permite la expresión, como una suerte de "metamedio». En el ámbito concreto de las prácticas artísticas, Peter Weibel habla de la necesidad de definir el estado actual como una nueva "condición postmedia", puesto que los medios ya no están aislados entre sí, sino que interactúan y se condicionan mutuamente: "El caudal de todos los medios forma un medio universal que se comprende a sí mismo. Éste es el estado postmedia del mundo de los medios en la praxis artística de hoy» (Weibel, 2005).

En consecuencia, aquellos medios visuales (como la fotografía y el cine) que se incorporan a la cultura digital se han reconvertido paulatinamente en híbridos visuales, cada vez más alejados de sus tradicionales sistemas de producción y sus viejos códigos.

«Más que de tecnologías nuevas, deberíamos hablar ahora de 'tecnologías híbridas', es decir, de aquellas que a través de las nuevas herramientas de software han conseguido trasvasar parte de su 'código genético' al nuevo soporte digital. La mayoría de los nuevos medios que difunden sus contenidos a través de la Web son ya una suerte de medios 'transgénicos'» (Gómez-Isla, 2008, p. 14) 
La "reconversión transgénica" de los medios analógicos tradicionales en nuevos medios digitales va a provocar que los límites categoriales (que hasta ahora habían servido para mantener de forma diferenciada los productos y narrativas propias de la pintura, la fotografía o el cine) hayan empezado a saltar definitivamente por los aires. Esta nueva era postmedia (Brea, 2002) nos obliga a repensar y reformular el concepto clásico de medios visuales tal y como los entendíamos hasta ahora. Y, a su vez, esta reconfiguración postmedial nos obliga también a reconsiderar las instituciones que hasta ahora los definían. Pero esa ya es otra historia.

\section{Conclusiones}

Los casos analizados por comparación entre distintos medios (plásticos y visuales) nos sirven como ejemplo sintomático del grado de permeabilidad que estos medios han desarrollado para tomar préstamos lingüisticos de otras prácticas situadas respecto a ellos en territorios fronterizos.

Sustentados por una industria cultural, que reúne y alberga sus productos visuales dentro de un corpus teórico y formal específico, cada medio se ha ocupado a lo largo de su historia en resolver un difícil dilema de autodefinición. La construcción lenta y paulatina de esa identidad propia, en tanto que disciplina autónoma, casi siempre sitúa a esos medios de forma equidistante, a caballo entre la tradición discursiva precedente y la revolución tecnológica presente. Por un lado, cada nuevo medio visual que aparece proyecta inevitablemente una mirada hacia el pasado, hacia la disciplina que le precede, y de la que se desgaja abruptamente cuando su propia tecnología entra en escena (para derribar casi siempre el orden establecido), pero de la que también se inspira claramente para construir su propio discurso. Por otro lado, las particularidades distintivas de cada medio -es decir, esa aparente idiosincrasia tecnológica con la que todos nacen- les permitirá también (como defendía Greenberg), buscar sus propias especificidades discursivas (esos atributos esenciales, según Batchen) para constituirse como lenguaje, más allá de los relatos sociales en vigor. Lo exclusivo de la naturaleza de cada medio negocia así con la tradición visual de los ya existentes.

Por otro lado -como defiende Tagg y también Batchen-, la fotografía, por ejemplo, nunca ha ostentado una identidad propia como medio, ya que, según ellos, «toda identidad depende del contexto" (Batchen, 2004, p. 27). Sin embargo, un segundo enfoque más abierto, que no conciba cada medio solo como fenómeno cultural, sino también y sobre todo como tecnología singular aplicada a una determinada construcción narrativa -con formas exclusivas de operar y generar sus propuestas discursivasahondará aún mejor en esas particularidades distintivas que lo definen como medio.

A caballo pues entre su propia innovación constructiva y las convenciones visuales vigentes (marcadas por contextos sociales y culturales que otorgan eventualmente un significado determinado a cada una de esas producciones), los medios visuales están abocados a una redefinición constante por medio de las instituciones que los soportan. Aunque, como ya hemos visto, en algunos casos la institución o las relaciones de poder social que las definen no son únicas ni específicas del medio.

De igual modo, como las propias instituciones mediáticas también han evolucionado con el paso del tiempo (a golpe de revoluciones tecnológicas), estas también han desplazado sus propias fronteras disciplinares. En consecuencia, los medios terminan siempre cuestionando su propia identidad en tanto que soportes tensionales 
de las relaciones de poder existentes en una determinada sociedad. Así, esas fronteras disciplinares se vuelven cada vez más inestables, difusas y porosas. Es en ese caldo de cultivo donde la contaminación lingüística entre medios permite el trasvase de postulados y préstamos constantes de ida y vuelta que hará que se enriquezcan y diversifiquen cada vez más.

La ganancia generada por esas influencias, contaminaciones y apropiaciones mutuas en el espacio de la intermedialidad permite ir rellenando los espacios en blanco que aún existen en esos territorios fronterizos entre disciplinas. A su vez, esta circunstancia les permitirá a los propios medios cuestionarse cada cierto tiempo su propia razón de ser, y evolucionar así hacia nuevos discursos y moverse también en otras nuevas direcciones.

\section{Bibliografía}

Alberti, Leon Battista (1511). Trattato della Pittura. [Versión en castellano: De la pintura, México D.F.: Servicios editoriales de la Facultad de Ciencias, UNAM, 1996]

Batchen, Geoffrey (1997). Burning with Desire. The Conception of Photography. Cambridge, USA: Massachusetts Institute of Technology. [Versión en castellano: Arder en deseos. La concepción de la fotografía. Barcelona: Gustavo Gili, 2004]

Baudelaire, Charles (1859). Le public moderne et la photographie, carta escrita a le Directeur de la Revue Française, París: Crítica al salón de 1859.

Bernard, Emile (1907). Recuerdos sobre Paul Cézanne, publicado en dos partes en el Mercure de France, del 1 al 16 de octubre de 1907. Recogido en el estudio crítico de M. Doran Sobre Cézanne. Conversaciones y testimonios. Barcelona: Gustavo Gili, 1980.

Brea, José Luis (2002). La era postmedia. Acción comunicativa, prácticas (post)artísticas y dispositivos neomediales. Salamanca: Centro de Arte de Salamanca (CASA)

Burgin, Victor (1982). Photography, Fantasy, Funtion, en: Thinking Photography. Londres: Mc Millan.

Cabanne, Pierre (1967). Entretiens avec Marcel Duchamp. Éditions Pierre Belfond, París. [Versión en castellano: Conversaciones con Marcel Duchamp, Barcelona: Anagrama, 1984.]

Daston, Lorraine; Galison, Peter (2007). Objectivity, Cambridge, Massachussetts: Zone Books, MIT Press.

Frizot, Michael (1984). Le temps contitué. Récit chronophotographique avec arrêts sur image, en el libro-catálogo Éttiene-Jules Marey, editado por el Centre National de la Photograhie de París, París: Photopoche.

Gaudreault, André; Marion, Philippe (2006). Cinéma et généalogie des médias, en Médiamorphoses, no. 16, Paris: Armand Colin, pp. 24-30.

Gómez-Isla, José (2008). Transgénesis mediáticas. Las particularidades discursivas de la Web como 'medio' o como 'metamedio', en Actas del Congreso I $+C$. Investigar la Comunicación. Congreso Fundacional de la Asociación Española de Investigadores en Comunicación. Santiago de Compostela, 30 de enero a 1 de febrero de 2008, pp. 1-17.

González García, Fernando (2019). Intermedialidad, institución y polisistemas. El cine como sistema dinámico: legitimación cultural e instituciones, en revista Caracteres. Estudios culturales y críticos en la esfera digital, Vol. 8, no. 1, mayo de 2019.

Greenberg, Clement (1960). The Modern Painting, en Forum Lectures, Washington D.C: Voice of America.

Herrera Navarro, Javier (1982). Pintura y fotografía. Historia de sus recíprocas relaciones, en Nueva Lente, $\mathrm{n}^{\circ}$ 119-120, julio-agosto de 1982, Madrid. 
Horacio: Epistula ad Pisones. (Siglo I A.C). [Versión en castellano: Arte Poética de Horacio o Epístola a Los Pisones. Traducción de Fernando Lozano, 1777. Createspace Independent Pub, 2013]

Lessing, Gotthold Efraim (1766). Laokoon oder über die Grenzen der Mablerey und Poesie. Berlín: 1766. [Versión en castellano: Laocoonte o sobre los limites de la pintura y la poesía. Madrid: Tecnos, 1990]

Manovich, Lev (2005). El lenguaje de los nuevos medios de comunicación. La imagen en la era digital, Barcelona: Paidós.

Marinetti, Filippo Tommaso (1909). Primer manifiesto del futurismo italiano, en periódico Le Figaro, 20 de febrero de 1909.

Micheli, Mario de (1979). Las vanguardias artísticas del siglo XX. Madrid: Alianza Editorial.

Moholy-Nagy, László (1929), Von Material zu Architektur, [Versión en castellano: La nueva visión, Buenos Aires: Ediciones Infinito, 1963]

Newhall, Beaumont (1964). The History of Photography from 1839 to the Present Day. Museum of Modern Art New York, 1964, pp. 30 y 31.

Paech, Joaquim (2010). A Institicionalização e a literarização do filme, en revista Contingentia, 5 (1), pp. 99-114.

Scharf, Aaron (1974). Art and Photography. Pelican Books, Harmondsworth [Versión en castellano: Arte y fotografía, Madrid: Alianza Editorial, 1994.]

Tagg, John (1988). The Burden of Representation. Nueva York: Macmilllan Publishers. [Versión en castellano: El peso de la representación. Ensayos sobre fotografías e historias, Barcelona: Gustavo Gili, 2005].

Weibel, Peter. La Condición Postmedial, en La Condición Postmedia. Madrid: Centro Cultural Conde Duque, 2006

Wendell Holmes, Oliver (1861). Sun-Painting and Sun Sculpture, en Atlantic Monthly, vol. 8, pp. 13-29. 